\title{
Institutionalized Ambiguity in Legal Status: Managing Citizenship in the U.S. Imperial Rule of the Philippines
}

Katrina Quisumbing King

University of Southern California

\begin{abstract}
A perennial question in the scholarship of the state asks how states rule and expand their capacity to do so. Scholars have paid special attention to activities that rationalize and build administrative capacity, known as legibility projects. Alongside these projects, state actors also rule through ambiguous and unclear techniques that have been given less scholarly attention. I introduce the concept of institutionalized ambiguity in legal status to extend the study of state rule. I ask what generates ambiguity, what purposes it serves in law and policy, and what consequences it has for the management of populations. I propose an analytic approach that draws attention to equivocation in law as enabling classificatory debates and discretion in the political realm. To illustrate the purchase of institutionalized ambiguity in legal status, I analyze how, during the years of formal imperial rule (1898-1946), U.S. state actors debated the racial fitness and membership of Filipinos in the imagined U.S. nation. I consider the broader implications of this analysis for scholars of modern state formation and suggest that foundational conflicts over national identity can be institutionalized in law, in turn facilitating a range of contradictory, but co-existing, legally defensible policies.
\end{abstract}




\section{Introduction}

There is a large body of scholarship on state formation that pays special attention to how states rule and expand their capacity to do so. One stream of this literature focuses on the techniques_-such as map-making and census-taking — state actors use to govern, make visible, rationalize, build state capacity, and expand infrastructural power (Centeno 1997; Emigh 2002; Emigh, Riley, and Ahmed 2015, 2016; Eyal 2006; Goldberg 1997; Hacking 1986; Loveman 2007a; Mann 1984; Mukerji 2009). These techniques have been called legibility projects (Scott 1998).

Alongside these projects, state actors also rule through techniques that evade legible definitions of territory and people. At times, they embrace ambivalence, ambiguity and vagueness in law and policy. Ambiguity in state rule is evident in variation across state institutional, unclear or broad laws, and discretionary implementation of law. Scholars have long emphasized that the state is not a monolith and called attention to within state variation (Adams, Clemens, and Orloff 2005; Mann 1986; McDonnell 2017; Steinmetz 1999). Modern states are divided by administrative organizations with specific functions, known as bureaucracies (Weber [1922] 1968). ${ }^{1}$ State agencies, and bureaucrats within them, have different interests and abide by different institutional logics (Chibber 2002; Fligstein 1987; Gilbert and Howe 1991; Heimer 1999), which can give rise to ambiguity in strategies of governance. Legal scholars draw attention to the interpretative space between law in the books and law in action (Pound 1910), referring to how law is often written in broad and vague ways leaving room for various interpretations (Benton 2010; Edelman 1992; Lerner 2011; Suchman and Edelman 1996). Scholars of the U.S. welfare state have shown that individual, local-level decision-making by "street-level bureaucrats" (Lipsky 1980) and discretionary programs are features of U.S. governance. Discretionary administration of social welfare benefits has disadvantage racial minorities, women, and people suspected of homosexuality (Canaday 2009; Fox 2012; Geva 2015; Katznelson 2005; Quadagno 1996; Schram et al. 2009; Schram, Soss, and Fording 2010). Ambiguous interpretation and implementation of state policies is consequential in the United States.

At the same time, in much contemporary sociology of the state, modern states are commonly framed as nation states ${ }^{2}$ in which the boundaries of territory enclose the population. It is a historical fact, however, that several putative nation states are imperial states (Chatterjee 1993; Cooper 2014; Fradera 2009; Frymer 2017; Go 2007, 2011; Jung 2015; McCoy, Scarano, and Johnson 2009; Rana 2010; Wilder 2005). The United States is one such state. In empire states, metropolitan state actors exercise political sovereignty over territories (through both direct and indirect means) and treat the indigenous populations of those territories as inferior (Barkey 2008:9; Steinmetz 2008a:591). ${ }^{3}$ Arendt ([1951] 1973) writes of the "inner contradiction" (151) of imperialism and nationalism, noting that "what imperialists actually wanted was an expansion of political power without the foundation of a body politic" (135). In the history of the United States, for instance, the pursuit of liberty, freedom, and democracy is interwoven with conquest, subordination, and exclusion of nonwhite others (Gerstle 2002; Smith 1997). Imperial rule is rife with contradictions,

\footnotetext{
${ }^{1}$ Weber defined bureaucracy as "characterized by formal employment, salary, pension, promotion, specialized training and functional division of labor, well-defined areas of jurisdiction, documentary procedures, hierarchical sub- and super ordination" ([1922] 1968: 1393).

2 See, for example, the work of Wimmer and colleagues (2010; 2006).

${ }^{3}$ Scholars of race and ethnicity and U.S. politics will recognize that this definition applies to the political structure of the United States, and in fact many states that consider themselves to be nations. 
and tensions, and metropolitan actors-like street-level bureaucrats of the welfare state-rely on brokerage and discretion in rule (Barkey 2008; Chatterjee 1993; Go 2008; Steinmetz 2008b; Stoler and Cooper 1997; Wilson 2011; Wyrtzen 2016). The study of these activities has been given less attention in the sociological literature on modern state formation.

Drawing on primary sources collected from over fifteen libraries and archives, I extend the study of ambiguity in state rule. I analyze an understudied part of U.S. history: the imperial management of Filipinos, which lasted from 1898-1946. This is a case of state management of populations, accomplished through legal decisions and legislation about citizenship. The aforementioned literature emphasizes legibility projects as expanding state capacity or explains ambiguity in state practice as an outcome of discretion or a feature of a federal, decentralized system of governance. These explanations cannot adequately account for the ambiguous and unclear treatment of Filipinos. During the 48 years of formal U.S. empire in the Pacific, U.S. legal scholars and professionals, politicians, and state bureaucrats debated the status, racial fitness, and membership of Filipinos in the imagined U.S. nation. In 1901, the U.S. Supreme Court decided that the Philippines and other territories from Spain were unincorporated, meaning they were "foreign in a domestic sense." Between 1934 and 1946, the U.S. Congress simultaneously classified Filipinos as citizens, nationals, and aliens according to different laws, which co-existed and did not overturn one another. Under the 1940 Nationality Act and the 1944 G.I. Bill, Congress promised juridical citizenship and social welfare benefits to Filipinos who served in the U.S. military. In 1946, after the close of World War II, Congress revoked these promises. U.S. classification of Filipinos vis-à-vis formal and social citizenship was ambiguous and discretionary. This is part of the history of how the United States became the United States, of how elites and state actors conquered and claimed new territory, expanded administrative capacity overseas, and ruled over new populations.

Through this case, I reveal a specific type of ambiguity in state rule, which I term institutionalized ambiguity in legal status. This type of legal ambiguity equivocates between two categories that should be mutually exclusive (like foreign and domestic). Institutionalized ambiguity in legal status constrains but does not determine future debates. It enables discretion by actors in the political realm, including legislators, colonial officials, and state bureaucrats. These political actors can then enact a range of classificatory possibilities-like Filipinos as citizens, nationals, and aliens. In this regard, institutionalized ambiguity in legal status is a second-order classification, or a classificatory background, that sets the terms for and enables first-order debates. "State bureaucracies not only interact with local populations in diverse and contradictory ways" (Rodríguez-Muñiz 2017:388), but also state actors create ambiguous legal statuses that have contradictory effects at the federal level. Institutionalized ambiguity in legal status is one tool through which state actors can manage conflicting interests that arise from the "many hands of the state" (Morgan and Orloff 2017).

\section{Legibility Projects and State Power}

Scholars, perennially interested in activities of state rule, have paid special attention to projects that rationalize and build administrative capacity, known as legibility projects. State officials engage in legibility projects when they take "exceptionally complex, illegible, and local social practices" and simplify them into "a standard grid whereby [these practices or customs] could be

\footnotetext{
${ }^{4}$ See Abend (2014) on the moral background as second-order (normative) morality without which first-order (behavioral) moral decisions cannot operate.
} 
centrally recorded and monitored" (Scott 1998:3). Activities like the creation of last names, the collection of demographic statistics, taxation, conscription, mapping, the standardization of language, and city planning are attempts by the state to simplify, manipulate, and build state power (Anderson 1991; Foucault 1997 [1976]; Scott 1998). In the opening of his book, Scott gives the example of beekeeping:

"In premodern times the gathering of honey was a difficult affair....The arrangement of brood chambers and honey cells followed complex patters that varied from hive to hive-patterns that did not allow for neat extractions. The modern beehive, in contrast, is designed to solve the beekeeper's problem....the wax cells are arranged neatly in vertical frames, nine or ten to a box, which enable the easy extraction of honey, wax, and propolis....From the beekeepers' point of view, the modern hive is an orderly, "legible" hive." (1998:3)

Legibility projects build capacity in modernist states, which are characterized by increasing calculability, formal rational legal and economic orders, and an organizational structure known as bureaucracy (Evans and Rauch 1999; Feldman 1991; Weber [1922] 1968). Through counting the population and mapping, states make visible and knowable that which and those whom they rule.

State actors count the population, register subjects or citizens, rationalize state revenue and military strength (Carroll 2006; Centeno 2011; Curtis 2002; Downing 1992; Ertman 1997; Mann 1993; Porter 1994; Starr 1987; Tilly and Ardant 1975). State categories serve administrative and symbolic purposes. They help define and create an imagined communities and concepts of race (Anderson 1991; Appadurai 1993; Hacking 1986; Jung and Almaguer 2004; Lee 1993; Loveman 2014; Mitchell 2002; Morning 2008). How state actors parse the population creates and advances the formation ideas and policies about citizenship and rights (Anderson 2015; Anderson and Fienberg 1999; Enloe 1981; Goldberg 2007:200; Lee 2008; Loveman 2014; Loveman and Muniz 2007; Nobles 2000; Prewitt 2013; Snipp 2003). Counting and defining the population and territory represents the state's capacity to represent and govern. By parsing the population into discrete cells, state actors define from whom they can expect taxes, military service, and other allegiances and to whom it must, in exchange, give benefits and rights.

By way of illustration: in regard to citizenship rights, those who were born within the territorial boundaries of the state or to parents considered of the state, are classified as citizens. Others, are aliens. These bureaucratic categories of citizen and alien are not natural, but constructed by officials like the material frames that hold modern, simplified beehives. This is evident in the variation in and between de jure practices of according rights and responsibilities to individuals as citizens (Brubaker 1992; Smith 1997). For instance, some countries define the legal status of citizen according to the principle of jus soli (meaning "right of the soil," or born within the territorial boundaries of the nation), while others adhere to jus sanguinis (meaning "right of blood," or born to a citizen). Jus soli and jus sanguinis are two different ways of simplifying reality. They represent ideas about human reality, of who belongs to the state and who does not. They set boundaries of insider and outsider-determining who fits into which cell. These legibility projects are one way of building state power. 
In the United States, government officials have used race-based criteria to define the boundaries of citizenship, denying social and juridical citizenship to racialized minorities. The 1789 Constitution excluded American Indians and made chattel slavery legal. ${ }^{5}$ The Naturalization Act of 1790 gave the right of naturalization to freeborn whites. This founding principle was then reinforced through Dred Scott v. Sandford (1857) which held that the word "citizens" in the Constitution did not, and did not intend to, include emancipated slaves. ${ }^{6}$ Who counted as white, and therefore who was a citizen, remained unsettled in the long twentieth century as the United States conquered new lands encountered growing waves of Asian labor migration. For example, the terms of the 1848 Treaty of Guadalupe Hidalgo-by which the United States annexed half of Mexico defined the new territory of the United States (Del Castillo 1992)—stipulated:

"Mexicans now established in territories previously belonging to Mexico, and which remain for the future within the limits of the United States, as defined by the present treaty.... may either retain the title and rights of Mexican citizens, or acquire those of citizens of the United States."7

After the U.S. conquest of Northern Mexico, the government gave many formal rights to inhabitants of the conquered territory, including the right to vote, own land, and naturalize as "free White persons" (Fox and Guglielmo 2012:352-53). Mexicans were legally defined as white and therefore made citizens. Whereas Mexicans could legally be admitted to the "white" cell, Asians could not. Citizenship was reaffirmed as contingent on white-European origin when the courts ruled that Japanese and Asian Indians were not white, and thus ineligible for citizenship (Haney-López 2006; Ngai 2004).

I do not mean to suggest that counting and defining the citizenry is clear cut, straightforward, or static. Indeed, state and nonstate actors disagree over and debate systems of classification and who should fit into which box (Haney-López 2006; Rodríguez-Muñiz 2017). Scholars have also shown how classifications may also change over time (Nobles 2000; Snipp 2003). At the same time, ideal-typical, de jure citizenship has not translated into a full extension of de facto rights, especially, in the U.S. context, for women and racial minorities (Fox 2012; Glenn 2002; Goldberg 2002; Smith 1997). Nevertheless, in this study, my focus is not on the gap between formal legible classifications and practice, how particular sets of actors debate and struggle over legitimate classification, nor on how classifications change over time. Rather, I am interested in how, at the level of the federal government, state actors produced definitions that could legitimately encompass what are typically thought of as competing and mutually exclusive legible statuses.

\footnotetext{
${ }^{5}$ In the Constitution, while the term "chattel slavery" is not mentioned, it does say: "No Person held to Service or Labour in one State, under the Laws thereof, escaping into another, shall, in Consequence of any Law or Regulation therein, be discharged from such Service or Labour, But shall be delivered up on Claim of the Party to whom such Service or Labour may be due" (U.S. Constitution. Article IV. Section 2).

${ }^{6}$ The exclusion of enslaved Africans from citizenship was superseded by the $13^{\text {th }}$ Amendment. Even then, however, the U.S. government continued to severely limit the rights of citizens classified as Black, as is evident in the 1896 ruling of Plessy v. Ferguson, in which the Supreme Court ruled that facilities for whites and Blacks could be "separate but equal."

7 Treaty of Guadalupe Hidalgo, 1848. Article VIII. 


\section{Ambiguity in State Rule}

In the scholarship on state rule less attention has been given to ambiguous state activities. ${ }^{8}$ Existing literature - much of which is in the Weberian tradition — on law in action, the welfare state, and colonial rule also suggest that state operations are not always uniform, clear, or simple. Though well-known for his attention to calculability and rationality, Weber himself acknowledged the tensions and ambiguity of modern state rule (Feldman 1991:217; Weber [1922] 1968:85-86; 880). The existing literature on what can be considered ambiguous state practices-variously defined by scholars as vague, evasive, and unclear language and practices-provides three (non-mutually exclusive) explanations for the sources of ambiguity: 1) variation in institutional or organizational culture; 2) unclear laws and policies; and 3) interpretative gaps between law and implementation.

\section{Variations in Institutional Culture}

Lack of legibility may stem from the multiple interests and competing logics within the state. State interests are not internally coherent. Bauman (1991), theorized that in fragmenting the state by powers and into areas of expertise, state actors generate ambiguity and ambivalence as byproducts. Politicians and bureaucrats also equivocate between political sovereignty (as in rules, laws, contracts) and war (as in lawless extraterritorial expansion) (Deleuze and Guattari 1987). ${ }^{9}$ They manage the contradiction between territorial expansion and the limitation of citizenship rights for the colonized (Arendt [1951] 1973). States may be deeply divided over foundational norms and ideas of who they represent (Lerner 2011; Smith 1997). At the same time, scholars have attributed lack of coherence to the fact that some states are organized in federal, decentralized systems. Scholars the U.S. state, in particular, emphasize not only federalism, but also delegation, and private-public systems of governance (Geva 2015:20; Mann 1984; Morgan and Orloff 2017:3; Novak 2008).

Ambiguity can emerge from lack of coordination and alignment among and within institutions ${ }^{10}$ at the central level of governance. ${ }^{11}$ For instance, ambiguity in practices can stem from tensions, contradictions, and contestation among organizations, which intersect and overlap (Mahoney and Thelen 2010:8; Mann 1986:15; Sewell 1992:16-19). Intraorganizational power struggles over resources and goals or different assessments of the organization contributes to lack of alignment among state institutions (Fligstein 1987). Just as lack of coherence within organizations can contribute to ambiguity, so too can serving different audiences and societal interests (Gilbert and Howe 1991; Heimer 1999). The lack of a central coordinating agency and "apportionment of power among state agencies" can also generate to ambiguity (Chibber 2002:951; 959). Institutions themselves can represent compromises among different coalitions (Palier 2005; Schickler 2001; Slater 2010). State agencies and organizations vary. Their institutional and organizational imperatives

\footnotetext{
${ }^{8}$ Levine argued that modern social science has neglected the study of ambiguity, and encouraged attention to the "constructive possibilities of ambiguity in theory and analysis" (Levine 1985).

${ }^{9}$ See also Novak (2008) on the tensions "between liberty and power, freedom and authority, contract and coercion, and law and violence” (754), in particular his references to Huntington (1981), Pound (1908), and Shaw (Shaw 1887).

${ }^{10}$ Following Clemens and Cook (1999:442), "institutions can mean formal law or state organizations."

$11 \mathrm{McD}$ onnell notes, however, that "less work focuses on the differences among state agencies and ministries comprising the central state apparatus," (McDonnell 2017:480 italics original). Indeed, much of the literature on lack of coordination points to variations across vertical dimensions of governance. Additionally, while not the focus of this article, it is important to recognize, as McDonnell (2017) does that "such state scholarship primarily views logics as derived from shared professional identity or organizational goals... This reflects a presumption, built into much of Western organizational theory, that individuals will identify with and align their efforts to their office...” (481). 
and interests do not always align. And coordinating among them can be one source of ambiguity in state practice.

\section{Unclear Law and Policy}

While we know that law is constitutive of state power (Novak 2008; Skrentny 2006; Witt 2010), scholars have also shown how law and legal definitions may be unclear and indeterminate (Edelman 1992; Suchman and Edelman 1996). Law is foundational for bureaucratic administration (Cotterrell 1995; Skrentny 2006; Weber [1930] 1992). While scholars debate the strength of the American state, ${ }^{12}$ many agree that "the United States is a distinctly legal or jural state" (Novak 2008:767). Law occupies an understudied, but "a central place...in state formation and policy development" (ibid). ${ }^{13}$

At the same time, laws are often written in broad and vague ways that contain analogies, generalities, and conflicting ideas. Societies that grapple with deep divisions over the definition of their national identity may rely on avoidance, ambivalent and vague legal language, and conflicting provisions in their constitutions (Lerner 2011). Political actors evade declaring official categorieslike national language_ _or do not make codes legally binding (ibid). Definitions or classification systems that are unclear as to who or what is included, can also result in ambiguity in treatment of these populations. State bureaucrats may overlook people who are viewed as strangers, "unfamiliars," "unclassifiables," or "undecidables" (Bauman 1991:53-61). Colonial subjects, for example, exist in hybrid and blurred spaces (Stoler and Cooper 1997:9), indeterminate states, or "zones of indifference," in which the boundaries between them and the colonizer are unclear (Fujitani 2011:48; 316). Even when the state creates classification systems, ambiguous definitions of religious minorities (Wyrtzen 2016), asylees and people in between immigration statuses (Menjívar 2006), and descendants of parents with different citizenship statuses (Kim 2016:31; Steinmetz 2008b:42; 101; 335) persist. People who do not easily fit into bureaucratic racial categories also experience ambiguity in trying to make sense of their racial identification and classification (Hobbs 2016; Mora 2014; Ocampo 2016; Rich 2014; Roth 2012; Waters 2009). Law and bureaucratic categories are simplifications of reality that do not always capture complex and diverse reality.

Just as law is sometimes broad and vague, government organizational policies and instructions can be complex and unclear (Lieberman 1998:16; Lipsky 1980:15; Naples 1991). Lack of clarity in rules has been consequential for individuals' claims to equality and social citizenship. For example, in the increasing bureaucratization during and after World War II, the U.S. Office of Veterans' Affairs (VA) produced, clarified, and regulated unclear categories as bases of exclusion from social welfare benefits. By taking advantage of the limbo between honorable and dishonorable discharge (known as a "blue discharge"), the VA denied benefits to veterans suspected of homosexuality (Canaday 2009). The lack of clarity in defining the terms active duty and veteran also allowed Congress to deny benefits to women who served in World War II (Scrivener 1999). ${ }^{14}$ The

\footnotetext{
12 Katznelson and Prewitt (1979), for example, have argued that law in the United States is important precisely because of America's relative statelessness.

${ }^{13}$ Witt (2010) also writes: "What would be nice to understand is the relationship between the American constitutional order and the emergence of American power.... How has the American constitutional system shaped the emergence of American strength on the world stage?" (775). A related set of literature has taken up the question of how war has impacted domestic rights (Bederman 2008; Capozzola 2008; Dudziak 2011; Foner 2011; Witt 2009).

${ }^{14}$ See Witsell, Edward to Edgar A. Sharp. 1946, February 19. RG 407. Entry 390A 472 Veterans, National Archives II, College Park MD: "I regret to inform you that the War Department cannot undertake to state what constitutes a quisumbing king
} 
federal government exercised little regulation over administrative agencies, allowing them to act on their own agendas. ${ }^{15}$ Flexible administration of the G.I. Bill resulted in discrimination against women, and those suspected of homosexuality. Elusive or vague, law, policy, and bureaucratic categories can be leveraged for exclusion.

\section{Interpretive Gaps and Discretion}

Laws and definitions are also ambiguous insofar as multiple interpretations can stem from one seemingly clear definition, phrase, or text (Bell and Hartmann 2007; Edelman 1992; Griswold 1987; Mahoney and Thelen 2010; Panofsky and Bliss 2017; Zuckerman 2004). Just as increasing bureaucratization enabled the production of unclear categories, decentralized governance so too can facilitate gaps between law and implementation. Formal laws are adapted and transformed by diverse local communities (Macaulay 1984; Suchman and Edelman 1996). In regard to colonial administration, for example, broad legal rubrics did not define how the colonies would be administered, and thus left available a great deal of discretion and invention to on the ground actors (Benton 2010:24). Interaction with local elites, gave rise to different and flexible structures of rule (Barkey 2008; Go 2008; Mehta 1997; Stoler and Cooper 1997). At the same time, metropolitan state actors applied different racial and civilizing schema to colonial subjects (Go 2004; Steinmetz 2008b; Thompson 2010). Go (2008), for example, documents how Puerto Rican and Filipino elite adapted Spanish and U.S. concepts of rule, drawing on their own ideals, symbols and narratives. Colonizers applied the "rule of colonial difference," (Chatterjee 1993) to maintain distinction between colonizer and colonized. Similarly, "the power of qualification" (stemming from a characterization of colonized people as sympathetic creatures on the one hand and as alien animals on the other) produced both "arbitrariness and intrinsic unconditionality" in the use of violence and multiple interpretations of and practices toward the colonized (Mbembe 2001:24-26). State actors claimed authority over marginal and subordinated territories and people in unclear ways, marked by "undecidability" in racial classification (Fujitani 2011) and "clamorous ambiguity" in the extension of rights (Fradera 2009:40). When local actors transform and adopt formal policy, state rule can be ambiguous.

Gaps between formal law and implementation are not only a challenge of colonial governance; administration of law and policy within the metropole is also marked by decentralized administration, discretion, and ambiguity. For example, scholars have demonstrated that social welfare agents of the 1930s and 1940s administered benefits in a decentralized fashion that resulted in racial inequality. ${ }^{16}$ Although the majority of these programs had explicit mandates from Congress to not discriminate and also had no formal citizenship-based exclusions (Katznelson and Mettler

\footnotetext{
'Veteran of World War II' except when required to administer a law in which the term is defined and used as a governing factor. Moreover, the word, 'veteran' is not an exact term, but is used in various specific and technical uses. For example, Title IV, Sec. 607 of the Servicemen's Readjustment Act of 1944, commonly known as the 'G.I. Bill of Rights' states: 'The term 'veteran' as used in this title shall mean a person who served in the active service of the armed forces during a war in which the United States has been, or is, engaged, and who has been discharged or released therefrom under conditions other than dishonorable'; whereas Title II, Sec. 400 (f) of the same act provides that 'Any person who served in the active military or naval forces on or after September 16,1940, and prior to the termination of hostilities in the present war, shall be entitled to vocational rehabilitation...."

15 For a description of ambiguity and the politics of legal enforcement, see Suchman and Edelman (1996:934).

${ }^{16}$ Here, I'm referring to New Deal Era social welfare programs. The G.I. Bill was not part of Roosevelt's New Deal, but I include it as a program of that Era, as Katznelson (2005) does in book. 
2008), ${ }^{17}$ local and state administrators discriminated against and excluded Mexicans and Mexican and Black Americans from accessing benefits in ways that they did not for European Americans and European immigrants (Fox 2012; Katznelson 2005; Onkst 1998; Rosales 2011). In debates over the 1944 G.I. Bill-well-known for providing educational benefits, job training, insurance, homeownership loans, and more to the veterans of World War II-southern Democrats demanded that Veterans Affairs (VA) administer it in a decentralized fashion (Katznelson 2005:20-21). In this era of the Jim Crow South, decentralized administration translated into discretion and inequality.

Decentralized administration of social welfare benefits is not unique to the G.I. Bill or the New Deal Era programs. Lower level bureaucrats and social welfare agents interpret and enact policy according to their individual rationales (Fording, Soss, and Schram 2011; Geva 2015; Korteweg 2003; Lieberman 1998; Mettler 1998; Naples 1991; Schram et al. 2010; Watkins-Hayes 2009). Street-level bureaucrats apply "substantive rationality that enables individuals to make caseby-case judgements;" in doing so, they rely on gendered and racialized assessments of worthiness (Geva 2015:172-73; 175). This has, in turn, disadvantaged racial minorities by excluding them from social welfare benefits. ${ }^{18}$ In this regard, ambiguity may be endogenous to the nature of work within some organizations. Case workers not only apply substantive rationality, but their jobs require "sensitive observation and judgement" (Lieberman 1998:15-16). They must assess the relationship among cultural tool kits, "client dilemmas and organizational mandates" (Watkins-Hayes 2009:33). The balancing of these organizational imperatives also influences discretion and may produce ambiguous results. The routine of social work requires flexibility. Both in colonial administration and U.S. social welfare programs, decentralized administration enables local actors to use discretion in interpreting and enacting laws and policy.

The forgoing scholarship demonstrates that state practices are not always clear, univocal, or legible. Scholarly accounts provide three main ways to understand ambiguity in the state. Ambiguity can arise from institutional imperatives and variation across them. Ambiguity is a product of unclearly written law or policy. Ambiguity is also a byproduct of discretion, or gaps between law and implementation, which often stem from decentralized administration.

\section{Ambiguity and Authority}

That ambiguities exist in the state raises the question of how ambiguous aspects of state rule relate to the capacity to govern. The theoretical hallmarks of a strong state have long been based in studies of European state formation, which emphasize " $[\mathrm{u}]$ nification, centralization, rationalization, organization, administration, and bureaucratization" (Novak 2008:761). ${ }^{19}$ Traditionally, states that fail to meet the European ideal type were thought of as weak. For example-in a now all-but-waned

\footnotetext{
${ }^{17}$ In the context of the New Deal Era policies, federal exclusion on basis of national origin or citizenship was rare. Some programs even explicitly included aliens (See Appendix B for a summary of the terms of exclusion from New Deal Era social welfare policies.)

${ }^{18}$ Relatedly, scholars have shown that greater amounts of inequality are associated with periods of increased decentralized administration (Clemens 2006; Fording, Soss, and Schram 2011; Morgan and Campbell 2011). Indeed, in U.S. history, strides toward equal rights—such as in the Civil Rights Amendments and then the Voting Rights Acts of the 1960s-have depended on legal interventions from the central state (Minow 1990; Tushnet 1996). Minow (1990) discusses how both decentralized and centralized authority poses a threat to the pursuit of tolerance and equal rights. Also, Tushnet (1996) discusses how the U.S. federal system has drifted toward centralization. It is not unreasonable, therefore, to expect that state coordination, calculability, and legibility would be linked to greater equality in rights and protection for subordinated groups.

${ }^{19}$ See for example Tocqueville ([1835] 1969) and Skowronek (1982).

quisumbing king
} 
tradition $^{20}$ — scholars of the U.S. state, particularly those in American Political Development (APD) have pointed to decentralized modes of governance, horizontal organization (which give rise to discretionary implementation and ambiguity), and divided sovereignty as signs of state weakness (Badie and Birnbaum 1983; Hamilton and Sutton 1989; Weir, Orloff, and Skocpol 1988). Bauman (1991) argued that the multiplicity of state interests and visions creates ambivalence and contributes to the failure in imposing both social and symbolic order.

Ambiguity is not simply a source of uncertainty or confusion, but also facilitates the consolidation of power by privileged actors. Padgett and Ansell (1993), for example, argue that Cosimo de' Medici's multivocal actions fortified alliances among elite networks, enabled coordination, creating a powerful state. Beyond scholarship on a single sovereign, other scholars have shown that when faced with dilemmas and conflicts of interest, state actors may equivocate, engage in political balancing, and enact contradictory policies, which in tun can concentrate authority (Goldberg 2007; Slater 2010). Looser interpretations of law are associated with greater state capacity (Pedriana and Stryker 2004). Broadly defined and flexible policies can also obscure government commitment to resolving social problems, instead vesting power in privileged parties (Piven and Cloward 1971; Weir et al. 1988; Weir and Skocpol 1985). Ambiguity is sometimes emblematic of state strength.

The literatures on culture, knowledge, professions, and science and technology, although not specifically attending to the state, also suggest ambiguity can increase authority. Ambiguity can generate uncertainty among audiences, which can, in turn, enable the speaker deniability or embellishment of their claims (Levine 1985; McMahan and Evans 2018). Ambiguity increases the authority of those who make definitions. Ambiguity, defined as multivocality, allows individuals "scope for exercising their interpretive skills" (Griswold 1987:1111) and is associated with greater cultural power (as in the capacity of a work or idea to linger and be upheld) (ibid: 1105). ${ }^{21}$ Relatedly, ambiguity enables coordination, resists oversight, builds accountability with the public or across audiences, and produces authority among experts (Fourcade 2009; McMahan and Evans 2018; Panofsky and Bliss 2017; Porter 1996). Ambiguity can facilitate collaboration and compromise among parties from different institutional settings (Mora 2014; Panofsky and Bliss 2017). In short, ambiguity increases the durability of a text or object across time and among different actors.

When read together, these literatures on institutions, law, colonial governance, and the welfare state point to new areas of inquiry about the sources and consequences of ambiguity. While we know that law and policy are sometimes written in unclear, broad, or vague ways, we know less about why, intentionality, and what purpose such laws can serve. How are these ambiguities generated? We also know little about the role ambiguity plays in the relationship between law and policy. Scholarly accounts of ambiguity in practice consider it to be synonymous with discretionary decision making. At the same time, Is ambiguity always an outcome of interpretative gaps and substantive rationality? If laws themselves can be unclear, do they also produce discretion, not only in policy implementation, but also creation? Much of the aforementioned scholarship sees ambiguity as a byproduct of bureaucracy and decentralized administration. Does ambiguity operate with in the central apparatus of the state? How does it relate to state capacity to govern? What consequences

\footnotetext{
${ }^{20}$ See Novak (2008) and Adams (2010:790).

${ }^{21}$ See also Star and Griesemer (1989) on how "boundary objects" enable cooperation in heterogeneous, complex institutional settings.

quisumbing king
} 
does it have for rule? Finally, as Skrentny (2006) notes that there has been minimal attention to the role of law in analysis of the administration of the U.S. welfare states. This limits our understanding of "the positive role of law and courts in policymaking and statebuilding" (ibid: 214). What role do the courts and law play in generating ambiguity? And how does this relate to the administration of welfare benefits?

\section{Defining Institutionalized Ambiguity in Legal Status}

I explore the sources and consequences of laws that are not merely broad or vague, but rather intentionally written in ambiguous, equivocal ways. The ambiguity of some laws is a source, not only an outcome, of discretionary implementation among various state actors across institutions. Ambiguity in law can enable discretion and a range of classificatory possibilities in the political realm. The focus here is on the relationship between law and politics rather than on the vertical dimensions of state rule.

I term this type of ambiguity in U.S. federal law: institutionalized ambiguity in legal status. I refer to legal decisions, classifications, or statuses that equivocate and blend seemingly mutually exclusive meanings. (The roots of the word ambiguity mean to be driven in two directions.) My claim is not that state actors decide to create an ambiguous classifications with foresight about how it will be used in the future, but that they use ambiguous classifications to solve an immediate conflict. State actors can defer making a univocally clear decision over contentious issues through the institutionalization of ambiguity in legal status.

Whereas ideal typical legible classifications, like that of citizen and alien, create a de jure legible relationship between the state and people, ambiguous legal classifications leave room for interpretation. By institutionalizing ambiguous legal statuses, legal professionals can embrace heterogeneity and competing definitions. For example, the United States, like other empire states, classifies its colonial subjects as nationals, rather than the pre-existing legible categories of citizens or aliens (See Table 1.) The category of "national' is ambiguous in that it equivocates between definitions of citizen and alien. The meaning of national drives in both directions. State actors blend the allegiance and martial responsibility expected of citizens with the barriers to social inclusion applied to aliens. Such a classification, by virtue of being institutionalized, becomes "legible" as a state category. Nevertheless, the category of national — as an ambiguous legal category - is not a simplification or standardization of reality. By incorporating ambiguous classifications or definitions of peoples or territories into the legal systems and institutions of the state, state actors can defer a clear decision.

\section{TABLE 1 ABOUT HERE}

The equivocal nature of institutionalized ambiguity in legal status can also enable an array of future classificatory possibilities. Institutionalized ambiguity can increase the capacity of a multitude of actors to pursue their contradictory and competing interests in the political realm. Institutionalized ambiguity is a source, not an outcome, of discretionary implementation. Secondorder ambiguous legal classifications are a tool that provides multiple actors with multiple interests a range of legitimate, de jure possibilities in how they treat and classify people.

In this regard, institutionalized ambiguities in legal status are not the beginnings of path dependent processes. Though they can be thought of as "contingent events [that] set into motion 
institutional patterns or event chains" (Mahoney 2000:507-8), these patterns are not strongly deterministic. Instead, institutionalized ambiguities are flexible. They represent another pathway to discretionary decision-making and differential treatment. This discretion can be used at different political junctures to different ends. In this sense, the concept and findings presented here depart from much of the literature on the importance of history and sequencing in social science, which focuses on how possibilities or alternatives drop out, become less likely, or are suppressed (Abbott 1997; Mahoney 2000; Moore 1978:376-97; Pierson 2011). Institutionalized ambiguity enables not one path, but many.

Institutionalized ambiguity is not simply a tension of bureaucracy or the byproduct of a failure to impose order (Bauman 1991; Feldman 1991; Weber [1922] 1968). Rather, it is part of how state actors manage rule. Taken together, projects of legibility and ambiguity are two techniques of rule, part of the "peculiar array of distributive technologies of state action" that are "foundational of infrastructural governmental strength" (Novak 2008:767). Ambiguity, like legibility, can facilitate the expansion of state capacity within the workings of the central government.

\section{Casing U.S. Imperial Rule and Classification of Filipinos}

To illustrate the pay-off in attending to institutionalized ambiguity, I leverage the history of U.S. rule and classification of Filipinos. Specifically, I focus on debates over who Filipinos were and how they and the Philippine territory fit into the U.S. "nation." I case ${ }^{22}$ this history in three ways. First, broadly, it is a case of state rule and population management, specifically carried out through laws and policies related to both juridical and social citizenship. Second, it is also a case of competing interests - most clearly expressed in debates over empire, expansion, and racial incorporation-among various legal professionals, politicians, and bureaucrats within a nonmonolithic state. Finally, when approached from the end of the story-the denial of social and juridical citizenship - it is a case of exclusion from benefits of the U.S. welfare state. What happened to Filipinos and how state actors debated, classified, and treated them cannot be explained sufficiently by existing theories on state rule (including those related to legibility, lack of coordination across institutions, unclear laws, or discretionary implementation). When cased with the exclusion of others from U.S. welfare benefits, what happened to Filipinos represents a deviant case (Emigh 1997). As such, the history of U.S. classification of Filipinos provides an entry point to illuminating the workings of ambiguity as an important aspect of statecraft. Institutionalization of ambiguity in law can facilitate the proliferation of future classificatory debates and possibilities.

The history of U.S. classification of Filipinos is not only a case of state management of populations through citizenship law and welfare policies, but represents a turning point or critical juncture $^{23}$ in U.S. rule. When the United States signed the Treaty of Paris in 1898 and took the island colonies from Spain, it embarked on a new project of expansion. The debates over the incorporation of the Philippine territory and people "aroused more political passion than any action by the Supreme Court since its decision in Dred Scott v. Sanford (1857)" (Sparrow 2006:5). And unlike the ruling from Dred Scott, the Court's decisions over the island inhabitants acquired from Spain (in what was known as the Insular Cases) have not been overturned. The acquisition of the territories was a

\footnotetext{
22 See Ragin and Becker's (1992) edited volume for discussions of different definitions of "case" and approaches to casing. Here, I use case as a verb (as in casing) in the sense that Ragin (1992) does. Cases also refer to "the products of basic research operations" (218).

23 See Abbott (1997) and Collier and Collier (1991).

quisumbing king
} 
watershed moment in which jurists not only changed the rule of law to accommodate overseas empire, but also lay down legal precedent that holds to this day (Burnett and Marshall 2001; Erman 2018; Sparrow 2006). The Insular Cases remade the constitution (Erman 2018) and transformed the U.S. notion of the "nation" from a corporate model to a singular nation-state (Thomas 2001:84; 8889). This imperial project "had a profound impact on the character of American statecraft" (Baldoz and Ayala 2013:77), transforming the constitution as it was known. "Colonialism was a crucible that plunged Washington's raw bureaucracy into the white heat of nationalist revolution and great power rivalry, forging new, heretofore unimagined state capacities" (McCoy et al. 2009:3). It is the history of U.S. classification of Filipinos in this overseas empire-and its durable place in the history of U.S. state formation — with which I am concerned.

Existing work on U.S. rule of the Philippines largely focuses on political projects between 1898 and 1916. The policies after 1934 through the end of World War II and their relationship to the projects of the early period of rule, meanwhile, remain underexplored. This is in part an artifact of colonial rule and war. The history of and data on citizenship and military service of Filipinos in the U.S. empire is fragmented by the multitude of actors and agencies involved in ruling the Philippines. Due to the institutional isolation of these records, the few analysts who have explored the 1934-1946 period primarily relied on the electronically available records of Congress. The documents of other state agencies, memos between Presidents and their staff, and the records of the Philippine government are underutilized.

To demonstrate the utility of the concept of institutionalized ambiguity in legal status, I rely on primary historical research and secondary source material. Drawing on data collected from over fifteen libraries and archives, ${ }^{24} \mathrm{I}$ use within-case comparisons ${ }^{25}$ to reconstruct the legal and political tools used by U.S. state actors to classify and ultimately exclude Filipinos from social and juridical citizenship. I gathered information on the laws and policies constructing Filipinos and the Philippines as belonging, or not, to the United States. I analyzed how different legal professionals, politicians, and bureaucrats understood colonial policy. I read and thematically organized judicial decisions, legal arguments, memos of members of the U.S. executive office and bureaucrats, Congressional debates, and colonial reports with attention to how U.S. elites navigated colonial responsibility and notions of inclusion and exclusion. In court cases and decisions, I looked for the types of comparisons made with existing precedent as well as different legal distinctions made in practice. In Congressional debates and records, I analyzed comparisons of political status, material and interest-based justifications for different policy, exploring the justifications for and consequences of these distinctions. In reports and memos of the executive office and bureaucrats, I looked for challenges in implementing policy as well as attempts to rationalize and justify policy.

I looked for how Filipinos' geographic origin, occupational status in the military, and notions of allegiance were invoked. I explored how colonialism, citizenship, and sovereignty intersected for the Philippines and Filipinos in the broader context of incorporation of racial minorities in the United States. Specifically, I asked: how did U.S. state actors debate the conquest of the Philippines? How did they settle conflicts over whether the colony would be incorporated into the United States? How did they classify the territory and people of the Philippines? How did state actors interpret and

\footnotetext{
24 See Appendix A for a list of archival sources.

${ }^{25}$ See Lange (2013), especially Chapters 3 and 4. Here, I use "case" to refer to the history of U.S. classification and treatment of Filipinos vis-à-vis laws and policies of social and juridical citizenship. 
use ambiguous classifications in imperial rule? And what were the consequences of these debates for the Philippines and Filipinos at the end of formal U.S. rule?

In identifying key actors and justifications for the classifications of Filipinos, I revealed a range of existing classifications. I also compared these classifications and policies found in primary documents to those already documented in existing secondary literature on U.S. military and social welfare benefits. This literature, however, did not sufficiently explain how or Filipinos were classified and treated in the ways they were. I then asked what made the co-existence of these classifications possible. I found that classificatory debates and possibilities were rooted in existing notions of responsibility and citizenship that dated back to the acquisition of the Philippines at the turn of the $20^{\text {th }}$ century.

\section{A New Racial Problem and Conflicting Interests}

The contradictions and ambiguities of U.S. rule are especially apparent in the activities of the U.S. empire state. Since the founding of the United States, federal actors wrestled with and managed conflicts over the implications of U.S. expansion for "national" identity and federalist versus centralized visions of governance (Frymer 2017; Rana 2010). Territorial conquest was built on notions of direct participation and economic independence through land ownership at the expense of American Indians (Rana 2010). The U.S. government used federal land policy to assert authority over newly claimed Indian territories and people (Frymer 2017). Activities such as conquering American Indians and expanding westward defined the territory and membership of the United States as one of and for free white men. Typically, those in favor of a strong federal government, supported territorial conquest while those in favor of state rights argued against expansion. Both camps viewed non-Europeans as outsiders to the nation, but debated whether to rule over them as subordinated subjects or exclude them wholesale from the polity. With the 1871 Indian Appropriations Act and the 1887 Dawes Act, the United States asserted sovereignty over Indian lands, by ending treaties and dividing reservations (Dunbar-Ortiz 2014; Horsman 1981). Americans Indians, by the ruling of Cherokee Nation v. Georgia (1831), ${ }^{26}$ were (and still are) considered "domestic dependent nations." They were not made U.S. citizens until the 1924 Indian Citizenship Act.

In 1898, U.S. politicians considered another territorial conquest as they debated intervening in Cuba's war for independence from Spain. After the U.S. Battleship Maine exploded the port of Havana, Congress and President McKinley set down the path of war (Hoganson 1998; Pérez 1998). Initially, the war only seemed to be contained to the Caribbean, but since Spain had territories in the Pacific, the Navy entered the islands of the Philippines, battling with the Spanish. Although the Navy and War Department saw claiming these islands as part of a coherent military strategy, McKinley actually did not want to take the Philippines (Love 2004:175). Nevertheless, having already intervened in Spanish territories in both the Caribbean and the Pacific, the United States laid claim to the island colonies of the Philippines, Puerto Rico, Cuba, and Guam. ${ }^{27}$ At this point,

\footnotetext{
${ }^{26}$ Cherokee Nation v. Georgia, 30 U.S. 1, 17 (1831)

27 The United States also formally acquired Hawaii in 1898, though not from Spain. According to Thompson (2010), neither Hawaii nor Cuba were an imperial problem. Despite the native population and migrant Asian laborers, Hawaii was deemed by authors of new possessions books as a white settler colony set for annexation (Thompson 2010:109-13). The racial make-up of Hawaii, however, was not so easily settled. (See, for example, Dominguez (1998)). State actors defined Cuba as a white-led country capable of self-rule for independence (at least nominally) (Thompson 2010:90-98).
} 
whether or not all state actors wanted the islands, they had them. The country was now embroiled in a bloody war with Filipinos, who sought their independence.

With the acquisition of the overseas territories from Spain, the United States faced with an imperial problem unlike before. Before 1898, territories acquired by the United States were either admitted as states or annexed for eventual statehood. For the most part, the non-indigenous people within them were eventually admitted as citizens. In this way, it was said that the Constitution followed the flag (both geographically and temporally). This popular phrase served as a short hand for asking "whether, if these territories were to be kept under U.S. sovereignty, they must eventually be granted statehood" (Burnett and Marshall 2001:4). Hawaii is an important exception to this, as Native Hawaiians gained the right to naturalize in 1900 with the passing of the Organic Act before Hawaii became a state. ${ }^{28}$ While the Constitution had followed the flag, it is also important to note that this shift in how the United States managed territories "did not suddenly inject racism into a hitherto nonracial practice of empire-state formation. Rather it laid bare the white supremacist underpinnings" (Jung 2015: 63). State actors had to reconcile these new territories and people with existing definitions of race, citizenship, and sovereignty (Burnett and Marshall 2001; McCoy et al. 2009; Sparrow 2006). The acquisition of and rule over the 1898 territories represent a departure from the preexisting ways of dealing with territory and people.

Although the war began over Cuba, debates over the incorporation of the territories centered on the incorporation of the Philippines (Erman 2018). One legal scholar of the time clearly summarized the nature of the debate:

Can the United States of America ever include a State erected on islands off the coast of Asia, and having no possible tie of connection with the American continent? ...Can they, then, annex such islands to a union into which they can never enter on equal terms? This question cuts deeper than the one propounded to the Supreme Court of the United States in the Dred Scott case. (Baldwin 1899:409 italics original)

In other words, what could be done with these people deemed to be inferior? The media, politicians and elites hotly debated the so-called "Philippine Question," akin to the "Negro Question," asking what could be done with these people deemed to be inferior? State actors and the media put the colonies on a racial evolutionary scale, comparing them to one another, arguing over if they could be civilized, how western they were, if they could be taught anything (Thompson 2010). These debates over race shaped policy about the colonies, determining if and how they would be incorporated. Among the prominent positions taken on these issues, no one argued that the Philippines should become a state or that its people should be treated as equal to U.S. citizens. The people of the former Spanish territories were considered anomalous to the U.S. racial order at the time (Go 2004; Kramer 2006; Thompson 2010). Virtually everyone agreed that Filipinos were racially unsuitable for incorporation into the United States. At the same time, many saw the islands' potential benefit as U.S. military outposts, a gateway to Asian markets, and extraction sites for natural resources.

Out of these assessments, emerged two competing positions over what to do with the islands. One set of legal scholars and politicians argued that the United States could not take the territories, even for their potential benefits (Baldwin 1899; Randolph 1898). According to them, the

28 PL 56-339. 1900. Hawaii Territorial Act. Section 100. 
rule of law, as defined by the U.S. Constitution, must follow the flag. If this were the case, then the territories eventually had to be incorporated as states, and the people within them given the rights of citizens. To take the islands and not set them on a path toward statehood would be unconstitutional. In the view of these scholars, territory and membership, sovereignty and citizenship must be coextensive. Because Filipinos were racially unsuitable as members of the United States, the United States should not claim sovereignty over the Philippines. The downside to this perspective was that it did not give the United States a justification for claiming the colonies, which it already had.

The second set of legal scholars and politicians, focusing on the potential benefits of claiming new overseas territory, argued that Constitution did not apply to the colonies (Langdell 1899; Thayer 1899). As such, the state could rule the colonies through military or executive orders, as in the time of war. The Philippines could be treated as subordinate to other U.S. territories. According to these thinkers, because the Constitution did not apply to the colonies, the United States need not consider the membership, responsibilities, or rights of the island inhabitants. The downside to this perspective was that it suggested Congress could arbitrarily bestow and take powers outside the terms of the Constitution, which would be undemocratic. Neither of these legal perspectives on the territories gave the United States judicial sanction to set some territories on a path to statehood (which was the only practice at the time) as the United States had done with Texas, New Mexico, California, for example, and to take others as simply subordinated territories.

A third position emerged that attempted to resolve the tension of territorial expansion and limitation of rights. This third view, which came to be known as the doctrine of incorporation, set the foundation for the legal ambiguities in the status of the colonies, including the Philippines. While the author of this position, Abbott Lawrence Lowell, agreed that the Philippines was unsuitable as a state, he also challenged the assumptions in the preceding positions. The primary objection to the first was the assumption that new territories are like the old, which has "no judicial sanction" (Lowell 1899:157). The point of contention with the second was that in addition to contradicting many judicial opinions, it allowed Congress to arbitrarily bestow and take powers. Lowell suggested that some territories could be annexed to become part of the United States, while others could be acquired "as not to form part of the United States" (Thompson 2010:190). Lowell proposed a legal definition of the United States as composed of territories prior to and after the writing of the Constitution. The territories organized before the Constitution followed it; those organized after followed treaties. In essence, it didn't matter if the Constitution followed the flag. The power to determine what happened to the territories rested, on the one hand, on Congress's power to make treaties, and on the other, Congressional discretion in setting the terms of the treaties. For example, depending on the treaty in question, some territories (such as Florida and those once forming Mexico) were to become states (Thompson 2010:190), while others-like the Philippines_could be managed as colonies. In suggesting this, Lowell created a legal argument for how the United States could restrict citizenship but expand sovereignty.

\section{The Insular Cases: Institutionalizing Ambiguity in Law}

These debates over the constitutionality of taking colonies and the definitions of U.S. territory and membership were transformed when the justices decided to treat the new colonies as distinct from previous territorial acquisitions. They institutionalized a new and ambiguous legal classification of the territories, which enabled discretion in future political decisions. Institutionalized ambiguity in legal status helped manage a conflict at the level of the federal government that resulted 
in a new constitutional order. The United States Supreme Court created a new strategy, through law, for managing expansion and racial rule.

The decisions from the Insular Cases, though mostly about Puerto Rico, were informed-and in fact haunted - by the preceding debates over the racial suitability of the Philippines (Erman 2018). At the same time, these cases "creat[ed] the constitutional underpinnings" of a new formation of U.S. empire (Erman 2008:6). One of the most cited cases from the era, Downes v. Bidwell (1901), contains the most detailed explanation of the doctrine of incorporation, first proposed by Lowell. As the aforementioned legal scholars presented three possible positions on dealing with the newly acquired territories, the decision of the Court was not a forgone conclusion. Indeed, the Court was hardly in agreement over the ruling. And like the earlier scholarly debates, the Justices were divided over the definition of the United States, the scope and applicability of the Constitution, the racial threat posed by island subjects, and subjects' potential rights as members. Not only did they rule in a 5-4 decision, but Justices wrote five separate opinions. The opinion of the court, written by one justice, Brown, created a new ambiguous legal status and institutionalized Congressional discretion. Two other Justices wrote concurring opinions, while two others wrote dissenting opinions.

Despite the lack of agreement, the Court created a new and ambiguous legal category for the Spanish territories: unincorporated territories. According to the opinion for the Court, written by Justice Brown, Puerto Rico's unincorporated status meant that it was "a territory appurtenant and belonging to the United States, but not a part of the United States..." 29 Brown also wrote that the United States did not included the territories, but referred only to states. Because Puerto Rico (and the other Spanish territories) belonged, but were not part of the United States, not all aspects of the Constitution need apply. Although Justice White did not agree with Brown that the United States only referred to states, he also argued for an ambiguous classification of the territories. ${ }^{30}$ He argued (affirmed by Shiras and McKenna), first, that the United States contained both states and territories, and second, that there were two types of territories. There were those which had promises of statehood and those which did not. Justice White called the second category of territories "unincorporated." White wrote that "in an international sense Puerto Rico was not a foreign country, since it was subject to the sovereignty of and was owned by the United States, it was foreign to the United States in a domestic sense, because the island had not been incorporated into the United States, but was merely appurtenant thereto as a possession." ${ }^{31}$ This second class of territories were neither clearly foreign nor unequivocally domestic. Brown, White, Shiras, and McKenna created an ambiguous definition of the Spanish territories that 1) belonged to but were not part of the United States and 2) were foreign in a domestic sense.

With this decision, the Court also sanctioned Congressional discretion. According to the opinion of the Court, Congress alone had the discretion to determine which parts of the Constitution would extend to the territories. This rested on Congress's plenary power ${ }^{32}$ and the power to make treaties. Referring to Congress's ability to determine if inhabitants of territories become "immediately upon annexation, citizens of the United States" and if "their children

\footnotetext{
29182 U.S. 244. 1901. Downes v. Bidwell.

30 According to Justice White, the Constitution operated everywhere, but the provisions would apply differently in different places.

31182 U.S. 244. 1901. Downes v. Bidwell.

32 Article IV, sec. 3, cl. 2 of the Constitution: "“"power to dispose of and make all needful rules and regulations respecting the territory or other property belonging to the United States." 
thereafter born, whether savages or civilized, are such entitled to all the rights, privileges and immunities of citizens," 33 Justice Brown supported the idea that Congress could decide the terms of U.S. imperial rule:

"We are also of opinion that the power to acquire territory by treaty implies not only the power to govern such territory, but to prescribe upon what terms the United States will receive its inhabitants, and what their status shall be in what Chief Justice Marshall termed the "American Empire." 34

In other words, the U.S. Supreme Court punted a decision on the status of the islands and gave Congress the power to determine what would happen to the newly acquired colonial subjects. Justice White's concurring opinion also upheld the notion of Congressional discretion.

Not all Justices, however, believed that the Court should endorse Congress's plenary power as a justification for ruling the territories and for U.S. empire. They saw this decision as legally unclear and ambiguous. In keeping with the popular opinion of most Democrats at the time, Chief Justice Fuller (joined by Brewer and Peckham) called White's opinion on Congressional discretion into question:

"the contention seems to be that, if an organized and settled province of another sovereignty is acquired by the United States, Congress has the power to keep it, like a disembodied shade, in an intermediate state of ambiguous existence for an indefinite period; and more than that, that after it has been called from that limbo, commerce with it is absolutely subject to the will of Congress, irrespective of constitutional provisions" 35

In Fuller's opinion, the Court's decision created ambiguity and gave unconstitutional powers to Congress. Justice Harlan, famous for his dissenting opinions on the Court, also believed the Court's decision on Congressional power violated the Constitution:

"Whether a particular race will or will not assimilate with our people, and whether they can or cannot with safety to our institutions be brought within the operation of the Constitution, is a matter to be thought of when it is proposed to acquire their territory by treaty. A mistake in the acquisition of territory, although such acquisition seemed at the time to be necessary, cannot be made the ground for violating the Constitution or refusing to give full effect to its provisions." 36

While he may not have approved of the initial acquisition of the Spanish territories, Harlan saw no justification for breaking with the Constitution. He wrote that he "reject[s] altogether the theory that Congress, in its discretion, can exclude the Constitution from a domestic territory of the United States." Harlan, also drawing attention to the lack of clarity in the Court's decision, went on to conclude, "I am constrained to say that this idea of 'incorporation' has some occult meaning which

\footnotetext{
33182 U.S. 244. 1901. Downes v. Bidwell.

34 ibid

35 ibid

36 ibid

37 ibid
}

quisumbing king 
my mind does not apprehend. It is enveloped in some mystery which I am unable to unravel." 38 Both Fuller and Harlan agreed that the Court created ambiguity for the territories in question. They were neither foreign nor domestic, but in what he considered a limbo, an in-between state. In other terms, the Court's decision on the territories was ambiguous in that it did not take a clear stance of foreign or domestic, but created room for the territories to be both.

Despite the four dissenting members, the Court ruled that the territories would be treated as "foreign in a domestic sense," meaning that they belonged to but were not part of the United States. The United States could claim the territory as its own, but need never set it on a path to statehood. According to this view, the Constitution guaranteed fewer rights in the colonies. It would apply to the colonies, but only insofar as been dictated by the treaties levied by Congress and federal statutes. The Supreme Court Justices, faced with competing positions on overseas empire, did not resolve the problem of whether the territories would be foreign or domestic. They deferred the issue by creating an ambiguous classification and ruling that the power to decide what happened in the colonies rested in Congressional discretion.

While the decision in Downes v. Bidwell instituted an ambiguous status for the Philippine territory vis-à-vis U.S. sovereignty, the question of the rights of the people within the new colonies was still up for debate. In a subsequent Supreme Court case (Gonzales v. Williams, 1904), the Court institutionalized a second ambiguity, ruling that inhabitants of the territories were nonaliens. The Justices, however, did not comment on the citizenship of colonial subjects (Erman 2018). The Court's ruling accommodated the vagueness of empire. From 1904 until 1934, however, Congress treated Filipinos as U.S. nationals, owing allegiance to the United States. ${ }^{39}$ Their status as nationals meant that despite the de jure exclusion of Chinese (and later others from the Asian region), Filipinos could freely migrate from 1898 until 1934 and held some rights given to citizens. In this period, then, Filipinos were neither simply foreign or domestic, nor citizen or alien.

Whereas justices could have chosen to exclude Filipinos and former Spanish subjects or treat them as aliens ineligible for citizenship, they created and instituted new equivocal legal statuses. Faced with ruling a new overseas territory and people, U.S. state actors and legal thinkers of the time debated their visions of the U.S. "nation." Some advocated for expansionism while others maintained isolationist positions. These positions reflected conflicting ideas about the geographic and demographic boundaries of the United States. Not only that, the conflict over incorporating or excluding the territory and its people came down to competing dictums of empire-territorial expansion alongside the subordination of exclusion of subjects living in those conquered territories. In its decisions, the Court defied earlier interpretations of the Constitution and definitions of the territory and membership of the United States. As legal scholars and historians have noted, these

\footnotetext{
38 ibid

${ }^{39}$ While not the focus of this article, Puerto Ricans were given formal, though limited citizenship in 1917 Jones Act. Scholars have suggested that this divergence in treatment of the Philippines and Puerto Rico could be due to various factors, including, but not limited to: the proximity of Puerto Rico to the United States; Puerto Rican elite and census enumerators successful claims of the whiteness of the island; Puerto Rican political figures linking their discourse of citizenship to metropolitan debates; and the lack of linguistic and tribal diversity in Puerto Rico. (Ayala and Bernabe 2009; Baldoz and Ayala 2013; Dominguez 2007; Erman 2018; Loveman 2007b; Loveman and Muniz 2007; Rafael 2000). Since 1898, Congress has debated 101 bills related to citizenship in Puerto Rico and enacted 11 overlapping citizenship laws. Over time, these bills have conferred three different types of citizenship to persons born in Puerto Rico (Erman 2018). See also McGreevey (2018) and Monge (1999).
} 
cases demonstrate "the capacity of law to generate new understandings and, therefore, new realities" (Rivera Ramos 2001:107). Specifically, through these cases, U.S. justices legitimated overseas imperial power by the United States, constituted a new legal and political subject, generated political flexibility, and created new legal and constitutional doctrine for the United States (ibid). These equivocal legal positions created a framework with new possibilities to defy foundational tenets of the state (as written in the Constitution).

Not only that, the justices avoided committing the United States to one, clear policy toward the territories. They enabled Congressional discretion. Rather than classify the Philippines as foreign or domestic or Filipinos aliens or citizens, then, the Court used new, ambiguous terms. "Indeed, one plausible way to understand ambiguous statutes is as devices for over-coming legislative contention by implicitly allowing each side to 'make a bet' on the out-come of subsequent interpretation. This technique has the political appeal of permitting the ultimate loser to plead good intentions and to decry the sorry perversion of 'legislative intent."' (Suchman and Edelman 1996:934). Ambiguity institutionalized in law, and not legibility or decentralized administration, allowed the U.S. federal government flexibility. The Court gave Congress the legal justification for both including and excluding the territories and their inhabitants. The decisions frown Downes and Gonzales allowed the U.S. to have its cake and eat it too, so to speak - to claim territory, but not people.

\section{The Proliferation of Citizenship Statuses}

The classification of the Philippines as foreign-in-a-domestic sense and Filipinos as noncitizen aliens and then nationals permitted future Congressional discretion and fluidity in first-order population classification in policy. Between 1934 and 1946, Congress's definitions of the Philippines and Filipinos expanded to include Filipinos as citizens of the United States, Filipinos as alien, and Filipinos as neither foreign nor domestic, or nationals (Table 2). No classification overturned a previous one. Rather, these definitions of Filipinos and the Philippines coexisted. Congress could not only classify the colony in many ways, but also expand U.S. sovereignty without the reciprocal extension of rights. This had the effect of creating maximum benefit for the United States at the expense of Filipino subjects. This is not surprising, but this was all completed under the rule of law. I provide four examples of how Congress debated and justified classifying Filipinos as aliens, citizens, and nationals.

\section{TABLE 2 ABOUT HERE}

First, in a seeming step toward the unambiguous clarification of Filipinos' citizenship status, Congress passed the 1934 Tydings-McDuffie Act. ${ }^{40}$ The main stated purpose of the act was to promise and define terms of independence for the Philippines after a 10-year period as a Commonwealth. The act also reclassified Filipinos as aliens, foreign to the United States. By the terms of the Act, the Philippines, though still a colony, "shall be considered a separate country" and "citizens of the Philippine Islands, who are not citizens of the United States shall be considered as if

\footnotetext{
40 Congress approved the first act, known as the Hare-Hawes-Cutting Act, in 1933 over the veto of President Hoover. (Representative Hare and Senator Hawes were Democrats. Senator Cutting was a Republican.) The Philippine legislature, however, did not accept the bill, as the President of the Philippine Senate, Manuel Quezon wanted to be the one to bring independence to the Philippines (rather than his political competition, Sergio Osmeña). Quezon brought a new bill of independence to the Philippines, known as the 1934 Tydings-McDuffie Act (almost identical to the earlier Hare-Hawes-Cutting Act). 
they are aliens." 41 The act both defined the territory and the people of the Philippines as foreign to the United States.

While they succeeded in formal classification of Filipinos as aliens in 1934, Congress built in contradictions to this status with in the very same act. Although Filipinos were aliens, they continued to owe allegiance, like citizens or nationals, to the United States. ${ }^{42}$ At the same time, Congress limited Filipino migration to a quota of fifty people per year. Fifty was more than other Asians were allowed in a year (zero), but also less than the minimum one-hundred-person quota allowed by the Immigration and Naturalization Service for non-Asian countries. ${ }^{43}$ Filipinos occupied a unique status as aliens that was between Asian and non-Asian. Ambiguity persisted.

Second, contrary to classifying Filipinos citizens of a foreign nation in the Tydings-McDuffie Act, and thus aliens in the United States, in the rising tide of World War II in relation to geopolitical security concerns, U.S. Congress considered Filipinos as citizens of the United States. In 1939, Congress passed a neutrality act in which the Philippines was considered part of the United States. The bill, which did not nullify the 1934 Tydings-McDuffie Act, provided that in a state of war, the President or Congress could issue proclamations to "promote security or preserve the peace of the United States or to protect the lives of citizens of the United States," defined to include the Philippines. ${ }^{44}$ Not only was Congress concerned with protecting its citizenry, which in this bill included Filipinos as inhabitants of the United States territory, they also wanted to secure the United States' economic interests in Asia:

"Another aspect of this whole matter of war and peace is entirely left out of consideration in this bill, and it seems to me that it is a much more important and serious matter as far as we are concerned. That is the situation in the Orient- the Far Eastwhere we need to watch our step, not only because of our interest in China, but also because of our interest and stake in the Philippines....We need become involved in Europe-but we are already involved in the Pacific with our $\$ 840,000,000$ of investments in the Philippines and our sovereignty over those very rich islands, which, under present law is to continue until 1946." 45

Because of U.S. investment and prospects for Asian trade relations, Congress viewed the Philippines as worth protecting and, therefore, worth including in the definition of the United States. In this regard, Congress thought it worth considering Filipinos as citizens, or as domestic to the United States. At this point, in 1939, by one law (the 1934 Tydings-McDuffie Act) Filipinos were classified as foreign aliens and, by another, they were citizens.

Third, Congress passed a different bill in 1940 that considered the Philippines to be neither foreign nor domestic. The Selective Service Act, passed September 16, 1940, read: "it shall be the

${ }^{41}$ PL 73-127. 1934. Philippines Independence Act of 1934.

42 PL 73-127. 1934. Philippines Independence Act of 1934; Section 2a1-2.

${ }^{43}$ Senator Shortridge suggested changing the quota from 100 to fifty. (H.R. 7233. 1932. "Philippine Independence" Congressional Record $72^{\text {nd }}$ Congress, $1^{\text {st }}$ Session, June 29: 14274.)

44 Among the many provisions of the bill, citizens were unable to travel on vessels of belligerent states, purchase, sell, or exchange bonds, securities, etc., to receive contributions from organizations or people from hostile governments, trade arms unless registered with the Secretary of State, or import or export arms.

${ }^{45}$ Congressional Record. June 28, 1939.

quisumbing king 
duty of every male citizen of the United States, and of every male alien residing in the United States...to present himself for and submit to registration" for the training of the armed forces of the United States. In the bill, the "United States when used in a geographical sense, shall be deemed to mean the several States, the District of Columbia, Alaska, Hawaii, and Puerto Rico." ${ }^{46}$ Because the United States was not defined to include the Philippines, Filipinos were not considered citizens.

While Filipinos were not citizens according to this bill, whether Filipinos were aliens was unclear. However, the passing of a special December 20, 1941 amendment to the act authorized military service by "citizens of the Philippine Commonwealth." ${ }^{47}$ And on January 3, 1942, the Selective Service System issued a directive stating that "[a]ll registrants who are citizens of the Philippine Commonwealth are deemed nationals of the United States and shall be reclassified in the same manner as citizens of the United States." 48 This suggests that by the aforementioned 1940 Selective Service Act, Filipinos were not considered citizens or aliens, but again nationals akin to their pre-1934 status. By issuing a special statement ensuring enrollment of Filipinos into the U.S. military, the Selective Service demonstrated the military's interest in taking advantage of all people who could fight on behalf of the United States in World War II.

Fourth, in the 1940 Nationality Act, Congress again considered Filipinos as foreign aliens. The express purpose of this act was to consolidate the laws about U.S. citizenship, naturalization, and expatriation. ${ }^{49}$ In the signed version of the act, Filipinos were not classified as citizens or nationals of the United States, as Congress defined the United States to only included Alaska, Hawaii, Puerto Rico, and the Virgin Islands.$^{50}$ Congress defined nationals of the United States as: "(1) a citizen of the United States, or (2) a person who, though not a citizen of the United States, owes permanent allegiance to the United States. It does not include an alien." ${ }^{\prime \prime}$ The signed version of the act excluded Filipinos from being classified as nationals. In the discussions over the bill, however, Representatives Rees and Austin, both Republicans, and Richard W. Flournoy, Assistant Legal Adviser of the State Department, debated Filipinos' status, determining that they were actually nationals:

"Mr. Flournoy: A Filipino could not take advantage of this [naturalization of residents of the United States]. ${ }^{52}$

Mr. Rees: A Filipino would not be a national.

Mr. Flournoy: Yes, he would.

\footnotetext{
4676 S. 4164. September 14, 1940.

4755 Stat. 844, Chap. 602. December 20, 1941/

48 The Filipinos who were enlisted after the special statement on the 1940 Selective Service Act were recruited and served in the United States. The First Filipino Infantry Battalion was formed in San Luis Obispo, CA in January 1942, and expanded to include a second regiment (Baldoz 2011:211-13). These individuals are known as the "First and Second Fil." 49 Representative1940. "Report to Accompany H.R. 9980," Report 2396. Committee on Immigration and Naturalization. $76^{\text {th }}$ Congress $3^{\text {rd }}$ Session. June 5.

50 PL 76-853. 1940. Nationality Act. Section 101d.

51 PL 76-853. 1940. Nationality Act. Section 101b.

52 From Section 321 of the signed act "A person not a citizen who owes permanent allegiance to the United States, and who is otherwise qualified may, if he becomes a resident of any State, be naturalized upon compliance with the requirements of this Act, except that in petitions for naturalization filed under the provisions of this section, residence within the United States within the meaning of this Act shall include residence within any of the outlying possessions of the United States."
}

quisumbing king 
Mr. Rees: Yes; that is right. He would. All right." 53

Also:

"Mr. Rees: For example, Filipinos are nationals, because they are persons born in an outlying possession of the United States.

Mr. Austin: They may be nationals but not citizens of the United States. It may mean a person who, though not, a citizen of the United States, owes permanent allegiance to the United States." 54

In this debates over the bill, some Representatives referred to Filipinos as nationals to suggest they could not naturalize and owed allegiance. Owing allegiance, however, was not contingent on status as a citizen or national; when Filipinos were classified as aliens in the 1934 Tydings-McDuffie Act, they still owed allegiance. Nevertheless, by both the Tydings-McDuffie Act and the 1940 Nationality Act, Filipinos were classified as aliens ineligible for citizenship.

While the Act was seemingly clear on Filipinos' status as Asian aliens, martial service trumped their racial ineligibility for naturalization. According to the 1940 Nationality Act:

"The right to become a naturalized citizen...shall extend only to white persons and persons of African nativity and persons of African descent, and descendants of races indigenous to the Western Hemisphere: Provided, that nothing in this section shall prevent the naturalization of native-born Filipinos having the honorable service in the United States Army, Navy, Marine Corps, or Coast Guard...."55

This special provision for Filipino eligibility for naturalization is unique. No other colonial, ethnic, or racial category is mentioned in this way. Senator King, a Democrat, spoke in favor of including this clause on Filipinos saying:

"Filipinos, however, regardless of their loyal service to the Government, are discriminated against and are denied the opportunity of becoming American citizens... to deny them citizenship means to cast them out of the positions which they occupy, and to prevent them from obtaining any position whatever in the Government."

To King, Filipinos, with martial sacrifice, should have the opportunity for citizenship. He cast this as an effort to not discriminate, especially in light of Filipino loyalty. Although Congress and the INS classified Filipinos as alien and foreign to the United States, they did, with martial sacrifice have the opportunity to gain citizenship. There was very little opposition to this in the debates over the

\footnotetext{
${ }^{53}$ Speaking on HR 6127 superseded by HR 9980. 1940. "To Revise and Codify the Nationality Laws of the United States into a Comprehensive Nationality Code." Hearings before the Committee on Migration and Naturalization of House of Representations. $76^{\text {th }}$ Congress, $3^{\text {rd }}$ Session. February 28: 102

54 Ibid. p. 298

55 PL 76-853. 1940. Nationality Act. Section 303. this act was consistent with previous legislation from May 9, 1918, that stated: "a native born Filipino with service of 3 years in the United States Navy, Marine Corps, or United States Coast Guard" could be naturalized after honorable service.

${ }^{56}$ Senator King, speaking on H.R. 9980. 1940. "Revision and Codification of Nationality Laws—Conference Report," in Congressional Record, $76^{\text {th }}$ Congress, $3^{\text {rd }}$ session, October 4: 13184. 
Nationality Act. ${ }^{57}$ This right for Filipino military to naturalize, however, was revoked in the 1946 Rescission Act, signed into law on February 18, which I discuss in detail in the subsequent section.

In navigating multiple interests, members of Congress classified Filipinos in ways that could, when analyzed alone, be interpreted as steps toward unambiguous, legible classification.

Nevertheless, the simultaneous classification of Filipinos as citizens, nationals, and aliens (together with the exceptions to these classifications written into the various acts), point to how an equivocal classification, as in "foreign in a domestic sense" can facilitate classificatory flexibility in the political realm. The state composed of different bodies_-the War Department, Immigration and

Naturalization Services, as well as different parties and members of Congress-each who have their own interests that they are trying to realize through law. The proliferation of these seemingly contradictory classifications is attributable to the fact that the United States is an empire state that used ambiguity to manage its colonies. The institutionalized ambiguity of "foreign in a domestic sense" permitted a deferral in defining both the territory and membership of United States.

\section{Classificatory Debates and Exclusion from Citizenship}

Institutionalized ambiguity in legal status not only facilitated multiple classifications of juridical citizenship, but also enabled debates and eventual exclusion from both social and juridical citizenship. At the end of World War II, legal ambiguity and the debates it enabled had material consequences for over 200,000 Filipino veterans. Unlike the discretionary exclusion of Black and Mexican veterans at the hands of local bureaucrats, Filipino veterans were federally reclassified as having not served in active duty. The earlier institutionalization of ambiguous status was a key source of flexibility that made this decision possible. It gave members of Congress the legal justification to exclude these colonial subjects from the benefits and status promised to them.

The ambiguous status of Filipinos under U.S. law gave them no clear rights and allowed U.S. Congress to abrogate its promise. Filipino veterans (and all those who served for the U.S. Armed Forces, whether citizen, alien, or national) were promised military benefits and an expedited path to citizenship under the provisions of the 1944 G.I. Bill. ${ }^{58}$ In the 1946 Rescission Act, however, Congress declared retroactively that the military service of the Philippine Commonwealth Army (which later became USAFFE), the guerrillas, and the New Scouts would not be considered service for the United States. ${ }^{59}$ This reclassification was unlike what happened to other minority veterans of

57 “To Revise and Codify the Nationality Laws of the United States into a Comprehensive Nationality Code." 1940. Hearings before the Committee on Immigration and Naturalization. House of Representatives. $76^{\text {th }}$ Congress First Session on H.R. 6127 superseded by H.R. 9980. 76 ${ }^{\text {th }}$ Congress, 3 ${ }^{\text {rd }}$ session. Feb 20.

58 People of Native American, Puerto Rican, Hawaiian, Mexican, Chinese, Filipino, and Japanese descent, who according to Mettler's estimate, made up 1.6\% of the U.S. military in WWII, were, on the books, eligible for benefits (Mettler 2005:29). This estimate, however, does not include these Filipino veterans who were enlisted in the U.S. military in the Philippines and served with promises of compensation and benefits.

5979 H.R. 5158. February 18, 1946. At the time of the war, there were four classes of Filipino World War II veterans, not including those who, after the amendment to the 1940 Selective Service Act that allowed for the enlistment of Filipinos, were recruited and served in the United States. These individuals are known as the "First and Second Fil."59 First, the Old Scouts, the unit from the Spanish-American and Philippine-American Wars, were composed of about 12,000 individuals. Second, there was the Philippine Commonwealth Army-composed of approximately 120,000 individuals — which was incorporated into the U.S. military as the United States Armed Forces in the Far East (USAFFE) in 1941. The majority of Filipino WWII veterans were members of this military body. Third, the recognized guerillas served on behalf of the United States in World War II, and were, by order of the Philippine Commonwealth President, incorporated into USAFFE. Fourth, and finally, the U.S. Army recruited the New Scouts after October 1945. 
World War II, who were excluded through discrimination at the local level. The United States was able to go back on a promise to these Filipino veterans because of the legal precedent set in Downes v. Bidwell, which never clearly defined the relationship of the United States to the Philippines and Filipinos.

Just as in the period leading up to World War II, different state actors with different interests leveraged the ambiguous status of the Philippines to different ends. In revoking military benefits, members of the VA and Congress drew on the ambiguous status of the Philippines to argue that the Philippines was its own, independent country, that Filipinos were not citizens or subjects of the United States, and that the Filipino veterans were not military. Contrary to these positions, one administrator also argued that Filipinos were subjects of the United States and deserved compensation. All of these positions were made legally possible by the decision from Downes $v$. Bidwell.

First, Filipinos could be classified as foreign or aliens. General Omar Bradley, administrator of the VA, emphasized that after independence certain benefits (namely vocational training, educational benefits, and insurance) ${ }^{60}$ "would no longer be available to veterans, or to veterans not American citizens, residing in the Philippine Islands after independence is established." ${ }^{\prime 11}$ Bradley suggested that the United States and the Philippines should reach an agreement where the soon-to-be independent Philippines would take responsibility for these benefits. Bradley did not make a similar recommendation for any other colonial subjects or foreign nationals. He only constructed the Philippines as responsible for its citizens. In a similar fashion, Senator Hayden also emphasized that the Philippines was, at the time of debate over the 1946 Rescission Act, its own, independent country: "It was the view of the [Appropriations] committee that the approximately 200,000 Filipinos who first and last served in that army [USAFFE] did so because they fervently desired freedom for their country and not with the idea of acquiring the right to go to another country,"62 by which Hayden meant the United States. In this view, Filipinos fought to serve their country, which Hayden cast as independent from the United States. Although the Philippines was defined by the VA and Congress as a foreign nation (even before its independence), the VA did administer

Together the count of guerillas and the New Scouts were composed of about 70,000 individuals (Nakano 2002:208). Congress revoked military benefits from the last three classes of Filipino veterans. The Old Scout Filipino veterans are an exception to the Rescission Act. For my analysis, I refer to Filipino veterans to include all those from the Philippine Commonwealth Army (later USAFFE), the guerillas, and the New Scouts.

${ }^{60}$ Benefits under the G.I. Bill included: pension, insurance, insurance premium guaranty, retirement, out-patient treatment, burial allowances, vocational rehabilitation, education, or training, guaranty of loans for purchases of homes, farms, or business, readjustment allowances, hospital and domiciliary care, non-service connected disability compensation, and death pension (Servicemen's Readjustment Act of 1944, 78 S. 1767, 58 Stat. 294, Chap: 268 (1944); Omar N. Bradley to Harry S. Truman. October 31, 1945. WHCF: OF 1055; Truman Papers, Truman Library, Independence, MO.; United States Retraining and Reemployment Administration. 1944. Your Rights and Benefits: A Handy Guide For Veterans of the Armed Forces and Their Dependents. Washington, DC: Office of War Mobilization.)

${ }^{61}$ Bradley referred to a proposed amendment in H.R. 3522-S.1203. For this amendment, the VA already provided related data to the Congressional committees on Appropriations and Territories and Insular Affairs. This bill would "liberalize and clarify the laws pertaining to hospital treatment, medical care, domiciliary care, and related services, and for other purposes; to the Committee on World War Veterans' Legislation.” Omar N. Bradley to Harry S. Truman. 1945, October 31. WHCF: OF 1055; Truman Papers, Truman Library, Independence, MO.

62 Senator Hayden, speaking on H.R. 5604. 1946. "Loyalty of Filipino People." Hearings before the Subcommittee of the Committee on Appropriations Senate. $79^{\text {th }}$ Congress, $2^{\text {nd }}$ session. March 25: 45. 
veterans benefits to veterans abroad and alien veterans in the United States. ${ }^{63}$ They only took exception for Filipinos.

If the Philippines was foreign to the United States, then the expenditure for Filipino veterans could be constructed as unnecessary foreign aid. Senator Carl Hayden on the Senate Appropriations Committee also argued the expenditure would be too great, saying:

"There may be sound political reasons for keeping the Philippine Army and the guerillas on the American pay rolls. The money that they receive may also be needed as a means of relieving poverty and distress. Upon the other hand, if members of either of those organizations are entitled to the full benefits of the existing pension laws and the G.I. bill of rights, the American Government has assumed a very large obligation payable over the next 30 or 40 years." 64

Hayden also went on the record as saying that although the United States' does have a moral obligation to Philippine Army veterans, the G.I. Bill was "intended to benefit an American who served in the armed forces and who, upon his discharge from the service, returned to civil life in the United States, where American standards of living prevail." The U.S. government should adjust for the difference in cost of living and "help the Filipino people to help themselves," as in the money would be better spent somewhere else. Hayden argued:

"Where there was a choice between expenditures for rehabilitation of the economy of the Philippine Islands and payments in cash to Filipino veterans, I am sure it is better to spend any equal sum of money, for example, on improving roads and port facilities. What the Filipino veteran needs is steady employment rather than to depend for his living on a monthly payment sent from the United States." ${ }^{\prime 25}$

Hayden claimed to support the national reconstruction that would put Filipinos to work, rather than sending them money for promised social welfare benefits. Like politicians who argued against Black and Mexican people receiving New Deal era domestic social welfare benefits (Fox 2012; Katznelson 2005), Hayden saw Filipinos like potential (non-white) dependents.

Second, members of Congress not only argued that the Philippines was independent, they also constructed Filipino veterans as foreigners to the United States. Senator McKellar remarked that the United States is "paying them [Filipino veterans] the same salaries as the Americans. They are not American citizens at all. They are Filipinos. They have never been sworn into service, but we are paying them at the Regular Army ${ }^{66}$ rates." In effect, on the basis of their status as non-U.S. citizens and by calling into question their contract with the U.S. military, McKellar argued that Filipinos were not deserving of U.S. support in exchange for their service. While Filipino veterans' status as

63 103.9992 Correspondence with Veterans' Administration, Department of State, RG 59, National Archives, College Park, MD.

${ }^{64}$ Senator Hayden, speaking on H.R. 5604. 1946. "Letter From Senator Hayden to Secretary of War on Enlistment of Filipinos as Philippine Scouts, October 9, 1945." Hearings before the Subcommittee of the Committee on Appropriations Senate. 79th Congress, $2^{\text {nd }}$ session. March 25: 36..

${ }^{65}$ Senator Hayden, speaking on H.R. 5604. 1946. "Means of Aiding Filipino Veterans." Hearings before the Subcommittee of the Committee on Appropriations Senate. 79th Congress, 2nd session. March 25: 61.

${ }^{66}$ The Regular Army is composed of enlisted military (not drafted). They are permanent and on active duty. 
American citizens was unclear, they were certainly colonial subjects who were promised the same benefits as American G.I.s. Notably, other U.S. racial minorities and colonial subjects were remunerated for their service and afforded benefits under the G.I. Bill. ${ }^{67}$ Second, Filipinos were not paid the same as Americans, but at less than half. ${ }^{68}$ Third, McKellar's statement that Filipinos were not sworn into service is also false, as they were sworn in as the Philippine Commonwealth Army, under the service of the United States, and then called to service by Roosevelt in 1941. McKellar's interpretation of Filipinos' status emphasized their status as non-citizens over their colonial status.

Third, in addition to using the Philippine's status as a (soon-to-be) foreign country and casting Filipinos as foreign, some members of Congress relied on the ambiguous status of the Philippine Army in order to revoke military benefits. Like McKellar, Senator Hayden (falsely) claimed that the non-Old Scouts were not military: "[ $t$ ] he assumption adopted by the War Department has been that the Philippine Army and the Philippine guerrillas were serving with but actually were not a part of "the armed forces of the United States," ${ }^{69}$ and were thus not entitled to benefits. Hayden again invoked the costliness of paying non-Old Scout veterans in his claim that members of the Philippine Army were not U.S. military. Senators McKellar and Hayden called into question the contract that bound the non-Old Scouts to service for the United States, casting them not only as non-citizens, but also as non-military. In this view, Filipino veterans of USAFFE served, but were not part of, the United States, echoing back to the 1901 Supreme Court Decision, Downes $v$. Bidwell, in which Justice White opined that the territories belonged to but were not part of the United States.

Fourth, U.S. state actors not only argued that Filipinos were foreign, others were simultaneously able to make the case that Filipinos were part of the empire. High Commissioner of the Philippines, McNutt, saw Filipinos as loyal subjects of empire who should be given their due. In McNutt's initial letter voicing disapproval of the Rescission Act, he informed Truman that neither he nor anyone in the Philippines knew of the legislative rider attached to the bill that would bar Filipino veterans from benefits until the vetoed bill arrived in Manila "very recently" (only a week before the second bill was signed). McNutt objected to this legislative rider in a meeting with Congress and in letters to Truman. McNutt emphasized that these benefits for the non-Old Scouts "...cannot be considered a special grant to the Philippines as a nation, but is rather part of our national obligation to all our veterans who served so nobly in this war." ${ }^{70}$ According to McNutt, paying these benefits to veterans would give them a preferential position in the Philippine economy

\footnotetext{
${ }^{67}$ Another class of Filipino veterans in the Philippines, known as the "Old Scouts," who fought for the United States in the Spanish-American War, and Filipino units enlisted in the United States were not stripped of eligibility. Also, nonwhite veterans (including citizens of the U.S., colonial subjects, and foreign nationals) were eligible for the benefits under the G.I. Bill. Japanese Americans, while classified as enemy aliens by Congress, the War Department, and Immigration and Naturalization Services, could still enlist in the military and were recognized for their service. Black veterans made up 8.5\% of the U.S. military at the time (Mettler 2005:29). Approximately 500,000 Latinos fought in World War II (Allsup 1982), of whom about 15,000 were citizens of Mexico. According to the War Department, about 80,000 Puerto Ricans served for the U.S. Armed Forces (G.B. Walker, Jr. to Assistant Chief of Staff, G-1. 1944, August 24. RG 165. Entry 43. 14.32 Aliens and Naturalization. National Archives II, College Park, MD.). 62,000 Puerto Ricans were inducted into the U.S. Army between July 1, 1940 and August 31, 1945 (1948, Dec 2. Edward Witsell to Dorothy Gordon. RG 407201 Puerto Rico. National Archives II, College Park, MD.).

${ }^{68}$ See memo from Carlos P. Romulo to the Secretary of War. 1945, November 1. 2.7, Philippine Army, Osmeña Papers, National Library of the Philippines, Manila, Philippines.

${ }^{69}$ Senator Carl Hayden. Senate Hearing. March 25, 1946.

70 Paul V. McNutt to Harry S. Truman. February 11, 1947. WHCF: OF 1055. Truman Papers. Truman Library. quisumbing king 
and ensure that the "United States keeps a powerful hold on an important segment of the Philippine public." ${ }^{71}$ He continued, "Philippine Army veterans, including the heroic guerrillas, served outstandingly equally with any other units of the armed forces of the United States. The Philippine units, especially the guerillas, saw more desperate combat duty than almost any of our others." ${ }^{72}$ McNutt was concerned with securing geopolitical relations in the Philippines and making good on a commitment to a colony. For him, the budgetary issue was miniscule. He favored an interpretation of colonial policy and responsibility that emphasized U.S. sovereignty over the Commonwealth. They, however, did not receive the benefits promised to them.

U.S. politicians and bureaucrats relied on institutionalized ambiguity in law to make various and conflicting claims about the nature of U.S. responsibility to their colonial subjects. Ultimately, with the mounting costs of post-war rehabilitation and pressures to decolonize, the exclusion of Filipinos won out. The ambiguous classification of Filipinos and the resulting polysemy by which they were considered citizens, nationals, and aliens allowed U.S. officials to treat Filipinos as citizens of the Philippines. By imagining the Philippines as an independent country, U.S. state actors could justify excluding Filipinos from social and juridical citizenship. The status of the Philippines as not a colony like Puerto Rico (whose inhabitants were considered U.S. citizens by the 1917 Jones Act), but also not yet a foreign nation, like Mexico, for example, left the Philippines in another unclear state. U.S. officials were able to deny the benefits and promises made to other citizens, colonial subjects, and foreign nationals.

In short, although the original G.I. Bill was open to all veterans, U.S. officials went back on a promise and expelled over 200,000 Filipino veterans of World War II from the compact of citizenship. Congress and the VA were able to accomplish this reclassification, in a part, because of the Court's strategic refusal to make univocally legible a category of people. What happened to these Filipino veterans reflects a history of competing and contradictory classifications that resulted in retrenchment, legislated at the federal level. ${ }^{73}$ And while the revocation of military benefits from Filipino veterans is unique to the history of exclusions from the G.I. Bill, ambiguity as a tool of exclusion wielded by the state is not. This is part of a larger legacy of constructing a white national identity that erases the history of colonial racial domination by denying the experience of those who deserve compensation.

\section{Discussion}

This is a case of state rule and population management, exercised through law and policy relating to citizenship. This is also a case of competing interests over empire, expansion, racial incorporation, and the terms of belonging. And finally, this is a case of how state actors deny social welfare benefits. The co-existing classifications of Filipinos as citizens, nationals, and aliens, and their eventual exclusion from citizenship cannot be wholly explained by the existing literatures on legibility, variations in institutional culture, unclear law, or decentralized administration.

As I have shown through the history of U.S. management of Filipinos, institutionalized ambiguity in legal status allowed the United States to manage relations with its largest colony, the

\footnotetext{
${ }^{71}$ Paul V. McNutt to Harry S. Truman. February 11, 1947. WHCF: OF 1055. Truman Papers, Truman Library, Independence, MO.

72 Ibid.

73 C.f. Smith (1997)

quisumbing king
} 
Philippines. When the United States claimed sovereignty over the islands acquired from Spain, state actors debated what to do with the territory and its people and what this meant for U.S. "national" identity. Not only that, legal scholars and professionals, faced new questions of how to interpret the Constitution in light of the overseas empire. Faced with these contentious and controversial issues, the U.S. Supreme Court justices institutionalized ambiguity. This moment was a turning point in U.S. empire. The ambiguous legal status of Filipinos in the U.S. empire-as foreign in a domestic sense-was not merely broad or vague. The justices, in their definition of unincorporated territories, equivocated between excluding and including the Philippines and its inhabitants.

The literature on legibility would suggest that U.S. metropolitan actors could have leveraged exclusions on the basis of citizenship, race, or ethnicity. Filipinos could have been classified as Asian aliens ineligible for citizenship. Instead, the U.S. Supreme Court defied a clear, univocal classification, deciding that the territories and their people could be unincorporated, meaning they were "foreign in a domestic sense."

At the same time, institutionalized ambiguity is not simply a byproduct of bureaucratic administration, decentralized governance, or individual discretionary decision making. From the history of U.S. classification and treatment of Filipinos, it is clear that legal scholars and professionals intentionally advocated for and created ambiguous legal categories. This is a different type of classification. Although the meaning of the Philippines' status as an unincorporated territory was unclear, it was, more specifically ambiguous, blending aspects of foreign and domestic. The justices drove the Constitution toward both a new order of imperial expansion and the old standbys of racial exclusion. They equivocated in defining the relationship of the United States to the Philippines and Filipinos.

Discretion, in this case, did not arise from gaps between law on the books and law in action or the individual application of substantive rationality by local actors, but from the highest court. The judicial decision to classify the Philippines and other territories from Spain as "unincorporated territories" gave legal sanction for future discretionary decision making by Congress. These legal decisions set the terms for downstream, first-order classifications and classificatory debates in the political realm. Institutionalized ambiguity in legal status enabled future metropolitan state actors, from different and competing interests groups, to variably classify the population in ways that were not possible for non-colonial territories or states. Rather than excluded them the basis of alienage or race, members of Congress instead simultaneously classified Filipinos as nationals, citizens, and aliens.

The gap between law in the books and law in action cannot be explained through challenges of implementation from center to periphery. Rather, ambiguity was crucial in facilitating the persistence of inequality in citizenship and social welfare benefits. U.S. colonial officials or streetlevel bureaucrats could have relied on interpretive gaps between law and policy to exclude Filipino veterans. Instead, under the leadership of the Senate Appropriations Committee, Congress instituted a federal reclassification of these Filipino veterans as having not served in active duty, in effect changing the nature of their relationship to the metropolitan government. On the ground actors in the Philippines, like McNutt and Filipino elite were in favor of military benefits. Metropolitan U.S. politicians and bureaucrats leveraged ambiguity to justify the unequal distribution of resources and benefits in the context of national legal and social commitments to equity. In each of these 
moments, many interpretations of the status of the Philippines and Filipinos were not only legally possible but also defended by different U.S. state actors.

\section{Conclusion and Implications}

Analysis of U.S. management, classification, and exclusion of Filipinos has implications for sociological literatures on the state, empires, and race and nation. First, to the literature on states, I demonstrate that alongside legibility projects, state actors create and rely on ambiguity. Both are crucial tools of statecraft, but they serve different purposes. Whereas legibility helps state actors clearly define the territory and population, through institutionalized ambiguity, they can manage conflicts, heterogeneity, and multiplicity. Second-order ambiguity in legal status operates as a classificatory background; it facilitates the simultaneous and future pursuit of different agendas. To the existing literature on discretion and flexibility in rule, I demonstrate that ambiguity is not only found in the discrepancy between law in the books and law in action or in different, seemingly contradictory outcomes, but it can also enable discretion. Ambiguous classifications at the level of the federal government, in this case the U.S. Supreme Court, can shape future political debates and actions.

Scholars should scrutinize the sources, institutionalization, and productive functions of state activities that embrace ambiguity, heterogeneity, and equivocality. The analytical framework I provided here may serve as an entry point for analysis on these types of activities that make state rule possible. Scholars can ask questions such as: when else, and at what levels of governance, have state actors used ambiguous decisions or classifications and to what ends? What kind of ideas of people and place set the terms of debate and construct the possible categories? In what presuppositions are legal classifications grounded? Are there moments in which ambiguity is abandoned as a strategy for managing tensions of rule? What differentiates these from moments in which state actors continue to rely on ambiguity? Addressing these questions will contribute to broadened understanding and can lead us to rethink what we know about how modern states organize themselves.

The existence of ambiguity in state rule points to a second implication of this analysis: that ambiguity can be useful for addressing conflicts over rule. There is little disagreement among scholars that both imperial rule and the federal U.S. system is rife with tensions. Building on these contributions, I draw attention to a specific legal tool that enabled state actors to manage the tensions inherent to U.S. empire: institutionalized ambiguity in legal status. Through codifying equivocal legal statuses like "foreign in a domestic sense," state actors not only defied their own legal systems and definitions, but also created a framework in which a range of legitimate and legal classifications are possible. In contradistinction to Bauman (1991), an equivocal position (in the form of ambivalence or ambiguity) was not a byproduct of the modern state's attempt to order, but a solution to the competing traditions of a fragmented state. As this study makes clear, it is important to unmask sources of tension and conflict in the state and ask how such conflict may be productive. For instance, the United States is an imperial state in which some imagine it to be a nation state. Scholars can examine how the tensions of imperial rule are translated into state laws and practices, the kinds of strategies that state actors use to create and affirm commitments to empire, and how these activities facilitate territorial expansion and subordination.

A third implication of this work is to draw attention to another path of exclusion from social and juridical citizenship. This type of ambiguity (institutionalized in legal status) differs from the 
kind of discretion that local bureaucrats and social workers used to exclude other racial minorities from social welfare benefits. These ambiguous legal classifications encoded an equivocal status that created conditions for future political moves. The justices left options open for future politicians to make federal-level decisions about the territory and people on a case-by-case basis, all of which were legally defensible. Certain kinds of statuses are institutionalized in ways that make possible greater degrees of discretion at the federal level in the treatment of different populations. Some classifications, like foreign in domestic sense and national, can be legitimately mobilized and deployed for exclusion and differential incorporation. Institutionalized ambiguity of Filipinos' legal status has material consequences for people's lives.

Not only does the decision of "foreign in a domestic sense" continue to shape the lives of Filipino veterans and their families, it is the rule of law for the U.S. colonies. Puerto Rico, as an unincorporated territory, receives unequal funding for federal programs, is disadvantaged in trade law, and excluded from federal bankruptcy options, which have become especially consequential in the wake of Hurricane Maria (Torruella 2017; Valle 2019). American Samoans are still considered U.S. nationals, and while Puerto Ricans and Chamorros are technically considered U.S. citizens, they cannot vote for the U.S. President. They too maintain an ambiguous status even as they are formally classified as U.S. citizens. Ambiguity, then, and the possible decisions that flow from it continue to have implications for the rule of racialized populations and control of territory.

This study of ambiguity highlights the need to bring the politics of empire, law, citizenship, and race into the same frame. Because state actors use ambiguity to justify claiming territory and limiting rights, studying it encourages interrogation of the presumed territorial or national boundaries of states. Analyzing the sources and consequences of ambiguity in state rule also draws attention to how international and imperial policies shape racial inequality. Scholars can bring together the "interconnections between internal liberty and external subordination-the two faces of American freedom" (Rana 2010:13). They can ask questions such as: How have political and economic exploitation abroad shaped possibilities of citizenship and liberty within the territorial boundaries of the purported nation state? How has imperial rule been racially configured? And, complementary to this, how has domestic racial rule been shaped by imperial projects? Analysis of U.S. rule of the Philippines identifies how institutionalized ambiguity in legal status created a framework that enabled flexibility and maneuverability in future decisions over the territory and population. U.S. state actors took advantage of ambiguity in decisions over the inclusion and exclusion of the Philippine territory and people. The case of U.S. conquest, rule, and decolonization of the Philippines makes clear the centrality of institutionalized legal ambiguity in managing the tensions of empire. 


\section{References}

Abbott, Andrew. 1997. "On the Concept of Turning Point.” Comparative Social Research 16:85-106.

Abend, Gabriel. 2014. The Moral Background: An Inquiry into the History of Business Ethics. Princeton, NJ: Princeton University Press.

Adams, Julia. 2010. "The Puzzle of the American State... and Its Historians." The American Historical Review 115(3):786-91.

Adams, Julia, Elisabeth Clemens, and Ann Shola Orloff, eds. 2005. Remaking Modernity: Politics, History, and Sociology. Durham, NC: Duke University Press.

Allsup, Carl. 1982. The American G.I. Forum: Origins and Evolution. Austin, TX: University of Texas Press.

Anderson, Benedict. 1991. Imagined Communities: Reflections on the Origin and Spread of Nationalism. New York: Verso Books.

Anderson, Margo and Stephen E. Fienberg. 1999. Who Counts? The Politics of Census-Taking in Contemporary America: The Politics of Census-Taking in Contemporary America. New York: Russell Sage Foundation.

Anderson, Margo J. 2015. The American Census: A Social History. New Haven, CT: Yale University Press.

Appadurai, Arjun. 1993. "Number in the Colonial Imagination." Pp. 314-39 in Orientalism and the Postcolonial Predicament: Perspectives on South Asia. Philadelphia: University of Pennsylvania Press.

Arendt, Hannah. [1951] 1973. The Origins of Totalitarianism. New York: Harcourt, Brace and Company.

Ayala, César J. and Rafael Bernabe. 2009. Puerto Rico in the American Century: A History since 1898. Chapel Hill, NC: University of North Carolina Press.

Badie, Bertrand and Pierre Birnbaum. 1983. The Sociology of the State. Chicago: University of Chicago Press.

Baldoz, Rick. 2011. The Third Asiatic Invasion: Empire and Migration in Filipino America, 1898-1946. New York: New York University Press.

Baldoz, Rick and César Ayala. 2013. "The Bordering of America: Colonialism and Citizenship in the Philippines and Puerto Rico." Centro Journal 25(1):76-76.

Baldwin, Simeon E. 1899. "The Constitutional Questions Incident to the Acquisition and Government by the United States of Island Territory." Harvard Law Review 12(6):393-416. 
Barkey, Karen. 2008. Empire of Difference: The Ottomans in Comparative Perspective. Cambridge: Cambridge University Press.

Bauman, Zygmunt. 1991. Modernity and Ambivalence. Cambridge, MA: Polity Press.

Bederman, Gail. 2008. Manliness and Civilization: A Cultural History of Gender and Race in the United States, 1880-1917. Chicago: University of Chicago Press.

Bell, Joyce M. and Douglas Hartmann. 2007. "Diversity in Everyday Discourse: The Cultural Ambiguities and Consequences of 'Happy Talk." American Sociological Review 72(6):895-914.

Benton, Lauren. 2010. A Search for Sovereignty: Law and Geography in European Empires, 1400-1900. Cambridge: Cambridge University Press.

Burnett, Christina Duffy and Burke Marshall, eds. 2001. Foreign in a Domestic Sense: Puerto Rico, American Expansion, and the Constitution. Durham, NC: Duke University Press.

Cabotaje, Michael A. 1999. "Equity Denied: Historical and Legal Analyses in Support of the Extension of US Veterans' Benefits to Filipino World War II Veterans.” Asian Law Journal 6(1):67-97.

Canaday, Margot. 2009. The Straight State: Sexuality and Citizenship in Twentieth-Century America. Princeton, NJ: Princeton University Press.

Capozzola, Christopher. 2008. Uncle Sam Wants You: World War I and the Making of the Modern American Citizen. Oxford: Oxford University Press.

Carroll, Patrick. 2006. Science, Culture, and Modern State Formation. Berkeley, CA: University of California Press.

Centeno, Miguel Angel. 1997. "Blood and Debt: War and Taxation in Nineteenth-Century Latin America." American Journal of Sociology 102(6):1565-1605.

Centeno, Miguel Angel. 2011. "Who Counts, Rules": Comment on Ritajyoti Bandyopadhyay, "Politics of Achieving: Hawkers and Pavement Dwellers in Calcutta." Dialectical Anthropology 35(3):323-26.

Chatterjee, Partha. 1993. The Nation and Its Fragments: Colonial and Postcolonial Histories. Princeton, NJ: Princeton University Press.

Chibber, Vivek. 2002. "Bureaucratic Rationality and the Developmental State.” American Journal of Sociology 107(4):951-89.

Clemens, Elisabeth S. 2006. "Lineages of the Rube Goldberg State: Building and Blurring Public Programs, 1900-1940.” Pp. 380-443 in Rethinking Political Institutions: The Art of the State, edited by I. Shapiro, S. Skowronek, and D. Galvin. New York: New York University Press. 
Clemens, Elisabeth S. and James M. Cook. 1999. "Politics and Institutionalism: Explaining Durability and Change." Annual Review of Sociology 25(1):441-66.

Collier, Ruth Berins and David Collier. 1991. Shaping the Political Arena: Critical Junctures, The Labor Movement, and Regime Dynamics in Latin America. Princeton, NJ: Princeton University Press.

Cooper, Frederick. 2014. Citizenship Between Empire and Nation: Remaking France and French Africa, 1945-1960. Princeton, NJ: Princeton University Press.

Cotterrell, Roger. 1995. Law's Community: Legal Theory in Sociological Perspective. Oxford: Oxford University Press.

Curtis, Bruce. 2002. The Politics of Population: State Formation, Statistics, and the Census of Canada, 18401875. Toronto: University of Toronto Press.

Del Castillo, Richard Griswold. 1992. The Treaty of Guadalupe Hidalgo: A Legacy of Conflict. Norman, OK: University of Oklahoma Press.

Deleuze, Gilles and Félix Guattari. 1987. “1227: Treatise on Nomadology: The War Machine.” Pp. 351-423 in A Thousand Plateaus: Capitalism and schizophrenia. Minneapolis, MN: University of Minnesota Press.

Dominguez, Virginia R. 1998. "Exporting US Concepts of Race: Are There Limits to the US Model?” Social Research 65(2):369-99.

Dominguez, Virginia R. 2007. "When the Enemy Is Unclear: US Censuses and Photographs of Cuba, Puerto Rico, and the Philippines from the Beginning of the 20th Century." Comparative American Studies An International Journal 5(2):173-203.

Downing, Brian M. 1992. The Military Revolution and Political Change: Origins of Democracy and Autocracy in Early Modern Europe. Princeton, NJ: Princeton University Press.

Dudziak, Mary L. 2011. Cold War Civil Rights: Race and the Image of American Democracy. Princeton, NJ: Princeton University Press.

Dunbar-Ortiz, Roxanne. 2014. An Indigenous Peoples' History of the United States. Boston: Beacon Press.

Edelman, Lauren B. 1992. "Legal Ambiguity and Symbolic Structures: Organizational Mediation of Civil Rights Law.” American Journal of Sociology 97(6):1531-76.

Emigh, Rebecca Jean. 1997. "The Power of Negative Thinking: The Use of Negative Case Methodology in the Development of Sociological Theory." Theory and Society 26(5):649-84.

Emigh, Rebecca Jean. 2002. "Numeracy or Enumeration?” Social Science History 26(4):653-98.

Emigh, Rebecca Jean, Dylan Riley, and Patricia Ahmed. 2015. "The Racialization of Legal Categories in the First U.S. Census.” Social Science History 39(4):485-519. 
Emigh, Rebecca Jean, Dylan Riley, and Patricia Ahmed. 2016. Antecedents of Censuses from Medieval to Nation States: How Societies and States Count. New York: Springer.

Enloe, Cynthia. 1981. "The Growth of the State and Ethnic Mobilization: The American Experience." Ethnic and Racial Studies 4(2):123-36.

Erman, Sam. 2008. "Meanings of Citizenship in the US Empire: Puerto Rico, Isabel Gonzalez, and the Supreme Court, 1898 to 1905.” Journal of American Ethnic History 27(4):5-33.

Erman, Sam. 2018. Almost Citizens: Puerto Rico, the U.S. Constitution, and Empire. Cambridge: Cambridge University Press.

Ertman, Thomas. 1997. Birth of the Leviathan: Building States and Regimes in Medieval and Early Modern Europe. Cambridge: Cambridge University Press.

Evans, Peter and James E. Rauch. 1999. "Bureaucracy and Growth: A Cross-National Analysis of the Effects of 'Weberian' State Structures on Economic Growth.” American Sociological Review 64(5):748-65.

Eyal, Gil. 2006. The Disenchantment of the Orient: Expertise in Arab Affairs and the Israeli State. Palo Alto, CA: Stanford University Press.

Feldman, Stephen M. 1991. “An Interpretation of Max Weber's Theory of Law: Metaphysics, Economics, and the Iron Cage of Constitutional Law.” Law \& Social Inquiry 16(2):205-48.

Fligstein, Neil. 1987. “The Intraorganizational Power Struggle: Rise of Finance Personnel to Top Leadership in Large Corporations, 1919-1979.” American Sociological Review 44-58.

Foner, Eric. 2011. Reconstruction: America's Unfinished Revolution, 1863-1877. New York: Harper Collins.

Fording, Richard C., Joe Soss, and Sanford F. Schram. 2011. "Race and the Local Politics of Punishment in the New World of Welfare." American Journal of Sociology 116(5):1610-57.

Foucault, Michel. 1997. "Society Must Be Defended": Lectures at the Collège de France, 1975-1976. Vol. 1. New York: Picador.

Fourcade, Marion. 2009. Economists and Societies: Discipline and Profession in the United States, Britain, and France, 1890s to 1990s. Princeton, NJ: Princeton University Press.

Fox, Cybelle. 2012. Three Worlds of Relief: Race, Immigration, and the American Welfare State from the Progressive Era to the New Deal. Princeton, NJ: Princeton University Press.

Fox, Cybelle and Thomas A. Guglielmo. 2012. "Defining America's Racial Boundaries: Blacks, Mexicans, and European Immigrants, 1890-1945.” American Journal of Sociology 118(2):327-79.

Fradera, Josep M. 2009. "Reading Imperial Transitions: Spanish Contraction, British Expansion, and American Irruption.” Pp. 34-62 in Colonial Crucible: Empire in the Making of the Modern 
American State, edited by McCoy, Alfred W. and Scarano, Francisco A. Madison, WI:

University of Wisconsin Press.

Frymer, Paul. 2017. Building an American Empire: The Era of Territorial and Political Expansion. Princeton, NJ: Princeton University Press.

Fujitani, Takashi. 2011. Race for Empire: Koreans as Japanese and Japanese as Americans during World War II. Berkeley, CA: University of California Press.

Gerstle, Gary. 2002. American Crucible: Race and Nation in the Twentieth Century. Princeton, NJ: Princeton University Press.

Geva, Dorit. 2015. "Selective Service, the Gender-Ordered Family, and the Rational Informality of the American State." American Journal of Sociology 121(1):171-204.

Gilbert, Jess and Carolyn Howe. 1991. "Beyond" State vs. Society": Theories of the State and New Deal Agricultural Policies." American Sociological Review 204-220.

Glenn, Evelyn Nakano. 2002. Unequal Freedom: How Race and Gender Shaped American Freedom and Labor. Cambridge, MA: Harvard University Press.

Go, Julian. 2004. “'Racism” and Colonialism: Meanings of Difference and Ruling Practices in America's Pacific Empire.” Qualitative Sociology 27(1):35-58.

Go, Julian. 2007. “The Provinciality of American Empire: 'Liberal Exceptionalism' and U.S. Colonial Rule, 1898-1912." Comparative Studies in Society and History 49(1):74-108.

Go, Julian. 2008. American Empire and the Politics of Meaning: Elite Political Cultures in the Philippines and Puerto Rico during US Colonialism. Durham, NC: Duke University Press.

Go, Julian. 2011. Patterns of Empire: The British and American Empires, 1688 to the Present. New York: Cambridge University Press.

Goldberg, Chad Alan. 2007. Citizens and Paupers: Relief, Rights, and Race, from the Freedmen's Bureau to Workfare. Chicago: University of Chicago Press.

Goldberg, David Theo. 1997. “Taking Stock: Counting by Race.” Pp. 27-58 in Racial subjects: Writing on race in America. New York: Routledge.

Goldberg, David Theo. 2002. The Racial State. Malden, MA: Blackwell Publishers.

Griswold, Wendy. 1987. "The Fabrication of Meaning: Literary Interpretation in the United States, Great Britain, and the West Indies.” American Journal of Sociology 92(5):1077-1117.

Hacking, Ian. 1986. "Making Up People.” Pp. 222-36 in Reconstructing individualism: Autonomy, individuality, and the self in Western thought, edited by T. C. Heller, S. Morton, and D. Wellbery. Stanford, CA: Stanford University Press. 
Hamilton, Gary G. and John R. Sutton. 1989. "The Problem of Control in the Weak State." Theory and Society 18(1):1-46.

Haney-López, Ian. 2006. White by Law: The Legal Construction of Race. New York: New York University Press.

Heimer, Carol A. 1999. "Competing Institutions: Law, Medicine, and Family in Neonatal Intensive Care." Law and Society Review 17-66.

Hobbs, Allyson. 2016. A Chosen Exile: A History of Racial Passing in American Life. Cambridge, MA: Harvard University Press.

Hoganson, Kristin L. 1998. Fighting for American Manhood: How Gender Politics Provoked the SpanishAmerican and Philippine-American Wars. New Haven, CT: Yale University Press.

Horsman, Reginald. 1981. Race and Manifest Destiny. Cambridge, MA: Harvard University Press.

Huntington, Samuel P. 1981. American Politics: The Promise of Disharmony. Cambridge, MA: Harvard University Press.

Jung, Moon-Kie. 2015. Beneath the Surface of White Supremacy: Denaturalizing U.S. Racisms Past and Present. Palo Alto, CA: Stanford University Press.

Jung, Moon-Kie and Tomás Almaguer. 2004. "The State and the Production of Racial Categories." Pp. 55-72 in Race and Ethnicity: Across Time, Space, and Discipline, edited by R. D. Coates. Leiden, Netherlands: Brill.

Katznelson, Ira. 2005. When Affirmative Action Was White: An Untold History of Racial Inequality in Twentieth-Century America. New York: W.W. Norton.

Katznelson, Ira and Suzanne Mettler. 2008. "On Race and Policy History: A Dialogue about the G.I. Bill.” Perspectives on Politics 6(3):519-37.

Katznelson, Ira and Kenneth Prewitt. 1979. "Constitutionalism, Class, and the Limits of Choice in US Foreign Policy." Pp. 25-41 in Capitalism and the State in U.S.- Latin American Relations, edited by R. Fagen. Stanford, CA: Stanford University Press.

Kim, Jaeeun. 2016. Contested Embrace: Transborder Membership Politics in Twentieth-Century Korea. Palo Alto, CA: Stanford University Press.

Korteweg, Anna C. 2003. "Welfare Reform and the Subject of the Working Mother:'Get a Job, a Better Job, Then a Career." Theory and Society 32(4):445-80.

Kramer, Paul A. 2006. The Blood of Government: Race, Empire, the United States, and the Philippines. Chapel Hill, NC: University of North Carolina Press.

Langdell, Christopher Columbus. 1899. "The Status of Our New Territories.” Harvard Law Review 365-92.

quisumbing king 
Lange, Matthew. 2013. Comparative-Historical Methods. Thousand Oaks, CA: Sage.

Lee, Sharon M. 1993. "Racial Classifications in the US Census: 1890-1990." Ethnic and Racial Studies 16(1):75-94.

Lee, Taeku. 2008. "Race, Immigration, and the Identity-to-Politics Link." Annual Review of Political Science 11(1):457-78.

Lerner, Hanna. 2011. Making Constitutions in Deeply Divided Societies. Cambridge: Cambridge University Press.

Levine, Donald N. 1985. The Flight from Ambiguity: Essays in Social and Cultural Theory. Chicago: University of Chicago Press.

Lieberman, Robert C. 1998. Shifting the Color Line: Race and the American Welfare State. Cambridge, MA: Harvard University Press.

Lipsky, Michael. 1980. Street-Level Bureaucracy: Dilemmas of the Individual in Public Service. New York: Russell Sage Foundation.

Love, Eric T. L. 2004. Race over Empire: Racism and US Imperialism, 1865-1900. Chapel Hill, NC: University of North Carolina Press.

Loveman, Mara. 2007a. "Blinded like a State: The Revolt against Civil Registration in NineteenthCentury Brazil." Comparative Studies in Society and History 49(1):5-39.

Loveman, Mara. 2007b. "The US Census and the Contested Rules of Racial Classification in Early Twentieth-Century Puerto Rico.” Caribbean Studies 35(2):79-114.

Loveman, Mara. 2014. National Colors: Racial Classification and the State in Latin America. New York: Oxford University Press.

Loveman, Mara and Jeronimo O. Muniz. 2007. "How Puerto Rico Became White: Boundary Dynamics and Intercensus Racial Reclassification.” American Sociological Review 72(6):915-39.

Lowell, Abbott Lawrence. 1899. "The Status of Our New Possessions: A Third View." Harvard Law Review 13(3):155-76.

Macaulay, Stewart. 1984. "Law and the Behavioral Sciences: Is There Any There There?” Law \& Policy 6(2):149-87.

Mahoney, James. 2000. "Path Dependence in Historical Sociology." Theory and Society 29(4):507-48.

Mahoney, James and Kathleen Thelen. 2010. “A Theory of Gradual Institutional Change.” Pp. 1-37 in Explaining Institutional Change: Ambiguity, Agency, and Power, edited by J. Mahoney and K. Thelen. Cambridge: Cambridge University Press.

Mann, Michael. 1984. "The Autonomous Power of the State: Its Origins, Mechanisms and Results." European Journal of Sociology/Archives Européennes de Sociologie 25(2):185-213. 
Mann, Michael. 1986. The Sources of Social Power: A History of Power from the Beginning to AD 1760.-1986. Cambridge: Cambridge University Press.

Mann, Michael. 1993. The Sources of Social Power: Volume 2, The Rise of Classes and Nation-States, 17601914. New York: Cambridge University Press.

Mbembe, Achille. 2001. On the Postcolony. Berkeley, CA: University of California Press.

McCoy, Alfred W., Francisco A. Scarano, and Courtney Johnson. 2009. "On the Tropic of Cancer: Transitions and Transformations in the US Imperial State." Pp. 3-33 in Colonial Crucible: Empire in the Making of the Modern American State, edited by McCoy, Alfred W. and Scarano, Francisco A. Madison, WI: University of Wisconsin Press.

McDonnell, Erin Metz. 2017. "Patchwork Leviathan: How Pockets of Bureaucratic Governance Flourish within Institutionally Diverse Developing States." American Sociological Review 82(3):476-510.

McGreevey, Robert C. 2018. Borderline Citizens: The United States, Puerto Rico, and the Politics of Colonial Migration. Ithaca, NY: Cornell University Press.

McMahan, Peter and James Evans. 2018. "Ambiguity and Engagement." American Journal of Sociology 124(3):860-912.

Mehta, Uday S. 1997. "Liberal Strategies of Exclusion.” Pp. 59-86 in Tensions of Empire: Colonial Cultures in a Bourgeois World, edited by F. Cooper and A. L. Stoler. Berkeley, CA: University of California Press.

Menjívar, Cecilia. 2006. "Liminal Legality: Salvadoran and Guatemalan Immigrants' Lives in the United States.” American Journal of Sociology 111(4):999-1037.

Mettler, Suzanne. 1998. Dividing Citizens: Gender and Federalism in New Deal Public Policy. Ithaca, NY: Cornell University Press.

Mettler, Suzanne. 2005. Soldiers to Citizens: The GI Bill and the Making of the Greatest Generation. Oxford: Oxford University Press.

Minow, Martha. 1990. "Putting up and Putting Down: Tolerance Reconsidered." Osgoode Hall Law Journal 28:409-48.

Mitchell, Timothy. 2002. Rule of Experts: Egypt, Techno-Politics, Modernity. Berkeley, CA: University of California Press.

Monge, José Trías. 1999. Puerto Rico: The Trials of the Oldest Colony in the World. New Haven, CT: Yale University Press.

Moore, Barrington. 1978. Injustice: The Social Bases of Obedience and Revolt: The Social Bases of Obedience and Revolt. White Plains, NY: M.E. Sharpe, Inc. 
Mora, G. Cristina. 2014. Making Hispanics: How Activists, Bureaucrats, and Media Constructed a New American. Chicago: University of Chicago Press.

Morgan, Kimberly J. and Andrea Louise Campbell. 2011. The Delegated Welfare State: Medicare, Markets, and the Governance of Social Policy. Oxford: Oxford University Press.

Morgan, Kimberly J. and Ann Shola Orloff, eds. 2017. The Many Hands of the State: Theorizing Political Authority and Social Control. Cambridge: Cambridge University Press.

Morning, Ann. 2008. "Ethnic Classification in Global Perspective: A Cross-National Survey of the 2000 Census Round." Population Research and Policy Review 27(2):239-72.

Mukerji, Chandra. 2009. Impossible Engineering: Technology and Territoriality on the Canal Du Midi. Princeton, NJ: Princeton University Press.

Nakano, Satoshi. 2002. "Nation and Citizenship in the Filipino World War II Veterans Equity Movement,1945-2011." Pp. 205-28 in “We the People” in the Global Age: Re-examination of Nationalism and Citizenship. Osaka: The Japan Center for Area Studies.

Naples, Nancy A. 1991. “Just What Needed to Be Done': The Political Practice of Women Community Workers in Low-Income Neighborhoods.” Gender \& Society 5(4):478-94.

Ngai, Mae M. 2004. Impossible Subjects: Illegal Aliens and the Making of Modern America. Princeton, NJ: Princeton University Press.

Nobles, Melissa. 2000. Shades of Citizenship: Race and the Census in Modern Politics. Palo Alto, CA: Stanford University Press.

Novak, William J. 2008. “The Myth of the 'Weak' American State.” The American Historical Review 113(3):752-72.

Ocampo, Anthony Christian. 2016. The Latinos of Asia: How Filipino Americans Break the Rules of Race. Palo Alto, CA: Stanford University Press.

Onkst, David H. 1998. “First a Negro... Incidentally a Veteran': Black World War Two Veterans and the G. I. Bill of Rights in the Deep South, 1944-1948.” Journal of Social History 31(3):51743.

Padgett, John F. and Christopher K. Ansell. 1993. "Robust Action and the Rise of the Medici, 14001434.” American Journal of Sociology 98(6):1259-1319.

Palier, Bruno. 2005. "Ambiguous Agreement, Cumulative Change: French Social Policy in the 1990s." Pp. 127-44 in Beyond Continuity: Institutional Change in Advanced Political Economies, edited by W. Streeck and K. Thelen. Oxford, UK: Oxford University Press.

Panofsky, Aaron and Catherine Bliss. 2017. "Ambiguity and Scientific Authority: Population Classification in Genomic Science.” American Sociological Review 82(1):59-87. 
Pedriana, Nicholas and Robin Stryker. 2004. "The Strength of a Weak Agency: Enforcement of Title VII of the 1964 Civil Rights Act and the Expansion of State Capacity, 1965-1971." American Journal of Sociology 110(3):709-60.

Pérez, Louis A. 1998. The War of 1898: The United States and Cuba in History and Historiography. Chapel Hill, NC: University of North Carolina Press.

Pierson, Paul. 2011. Politics in Time: History, Institutions, and Social Analysis. Princeton, NJ: Princeton University Press.

Piven, Frances Fox and Richard A. Cloward. 1971. Regulating the Poor: The Functions of Public Welfare. New York: Vintage Books.

Porter, Bruce D. 1994. War and the Rise of the State: The Military Foundations of Modern Politics. New York: The Free Press.

Porter, Theodore M. 1996. Trust in Numbers: The Pursuit of Objectivity in Science and Public Life. Princeton, NJ: Princeton University Press.

Pound, Roscoe. 1908. "Liberty of Contract.” Yale Law Journal 18:454-87.

Pound, Roscoe. 1910. "Law in Books and Law in Action." American Law Review 44:12-36.

Prewitt, Kenneth. 2013. What Is Your Race?: The Census and Our Flawed Efforts to Classify Americans. Princeton, NJ: Princeton University Press.

Quadagno, Jill. 1996. The Color of Welfare: How Racism Undermined the War on Poverty. Oxford: Oxford University Press.

Rafael, Vicente L. 2000. White Love: Census and Melodrama in the U.S. Colonization of the Philippines. Durham, NC: Duke University Press.

Ragin, Charles C. 1992. "Casing' and the process of social inquiry.” Pp. 217-26 in What Is a Case?: Exploring the Foundations of Social Inquiry, edited by C. C. Ragin and H. S. Becker. Cambridge: Cambridge University Press.

Ragin, Charles C. and Howard Saul Becker. 1992. What Is a Case?: Exploring the Foundations of Social Inquiry. Cambridge: Cambridge University Press.

Rana, Aziz. 2010. The Two Faces of American Freedom. Cambridge, MA: Harvard University Press.

Randolph, Carman F. 1898. "Constitutional Aspects of Annexation. Part First." Harvard Law Review 12(5):291-315.

Rich, Camille Gear. 2014. "Elective Race: Recognizing Race Discrimination in the Era of Racial Self-Identification.” Georgetown Law Journal 102:1501-72. 
Rivera Ramos, Efrén. 2001. 'Deconstructing Colonialism: The 'Unincorporated Territory' as a Category of Domination" edited by C. Duffy Burnett and B. Marshall. Foreign in a Domestic Sense: Puerto Rico, American Expansion, and the Constitution 104-19.

Rodríguez-Muñiz, Michael. 2017. "Cultivating Consent: Nonstate Leaders and the Orchestration of State Legibility.” American Journal of Sociology 123(2):385-425.

Rosales, Steven. 2011. "Fighting the Peace at Home: Mexican American Veterans and the 1944 GI Bill of Rights.” Pacific Historical Review 80(4):597-627.

Roth, Wendy. 2012. Race Migrations: Latinos and the Cultural Transformation of Race. Palo Alto, CA: Stanford University Press.

Schickler, Eric. 2001. Disjointed Pluralism: Institutional Innovation and the Development of the U.S. Congress. Princeton, NJ: Princeton University Press.

Schram, Sanford F., Joe Brian Soss, and Richard Carl Fording. 2010. Race and the Politics of Welfare Reform. Ann Arbor, MI: University of Michigan Press.

Schram, Sanford F., Joe Soss, Richard C. Fording, and Linda Houser. 2009. "Deciding to Discipline: Race, Choice, and Punishment at the Frontlines of Welfare Reform." American Sociological Review 74(3):398-422.

Scott, James C. 1998. Seeing Like a State: How Certain Schemes to Improve the Human Condition Have Failed. New Haven, CT: Yale University Press.

Scrivener, Laurie. 1999. "US Military Women in World War II: The SPAR, WAC, WAVES, WASP, and Women Marines in US Government Publications." Journal of Government Information 26(4):361-83.

Sewell, William H. 1992. "A Theory of Structure: Duality, Agency, and Transformation.” American Journal of Sociology 98(1):1-29.

Shaw, Albert. 1887. "The American State and the American Man." The Contemporary Review 51:695711.

Skowronek, Stephen. 1982. Building a New American State: The Expansion of National Administrative Capacities, 1877-1920. Cambridge: Cambridge University Press.

Skrentny, John D. 2006. "Law and the American State." Annual Review of Sociology 32:213-44.

Slater, Dan. 2010. "Altering Authoritarianism: Institutional Complexity and Autocratic Agency in Indoensia." Pp. 132-67 in Explaining Institutional change: Ambiguity, Agency, and Power, edited by J. Mahoney and K. Thelen. Cambridge: Cambridge University Press.

Smith, Rogers M. 1997. Civic Ideals: Conflicting Visions of Citizenship in US History. New Haven, CT: Yale University Press. 
Snipp, C. Matthew. 2003. "Racial Measurement in the American Census: Past Practices and Implications for the Future." Annual Review of Sociology 29(1):563-88.

Sparrow, Bartholomew H. 2006. The Insular Cases and the Emergence of American Empire. Lawrence, KS: University Press of Kansas.

Star, Susan Leigh and James R. Griesemer. 1989. 'Institutional Ecology,Translations' and Boundary Objects: Amateurs and Professionals in Berkeley's Museum of Vertebrate Zoology, 190739." Social Studies of Science 19(3):387-420.

Starr, Paul. 1987. "The Sociology of Official Statistics.” Pp. 7-57 in The Politics of Numbers. New York: Russel Sage.

Steinmetz, George, ed. 1999. State/Culture: State-Formation after the Cultural Turn. Ithaca, NY: Cornell University Press.

Steinmetz, George. 2008a. "The Colonial State as a Social Field: Ethnographic Capital and Native Policy in the German Overseas Empire before 1914.” American Sociological Review 73(4):589_ 612.

Steinmetz, George. 2008b. The Devil's Handwriting: Precoloniality and the German Colonial State in Qingdao, Samoa, and Southwest Africa. Chicago: University of Chicago Press.

Stoler, Ann Laura and Frederick Cooper. 1997. "Between Metropole and Colony: Rethinking a Research Agenda.” Pp. 1-56 in Tensions of Empire: Colonial Cultures in a Bourgeois World, edited by A. L. Stoler and F. Cooper. Berkeley, CA: University of California Press.

Suchman, Mark C. and Lauren B. Edelman. 1996. "Legal Rational Myths: The New Institutionalism and the Law and Society Tradition." Law \& Social Inquiry 21(4):903-41.

Thayer, James Bradley. 1899. “Our New Possessions.” Harvard Law Review 12(7):464-85.

Thomas, Brook. 2001. "A Constitution Led by the Flag: The Insular Cases and the Metaphor of Incorporation.” Pp. 82-103 in Foreign in a Domestic Sense: Puerto Rico, American Expansion, and the Constitution, edited by C. Duffy Burnett and B. Marshall. Chapel Hill, NC: Duke University Press.

Thompson, Lanny. 2010. Imperial Archipelago: Representation and Rule in the Insular Territories under US Dominion after 1898. Honolulu: University of Hawai'i Press.

Tilly, Charles and Gabriel Ardant. 1975. The Formation of National States in Western Europe. Princeton, NJ: Princeton University Press.

Tocqueville, Alexis de. [1835] 1969. Democracy in America. edited by J. P. Mayer. Harper Perennial.

Torruella, Juan R. 2017. “To Be or Not to Be: Puerto Ricans and Their Illusory US Citizenship.” Centro Journal 29(1):108. 
Tushnet, Mark. 1996. "Federalism and Liberalism." Cardozo Journal of International and Comparative Law 4:329-44.

Valle, Ariana J. 2019. "Race and the Empire-State: Puerto Ricans’ Unequal U.S. Citizenship." Sociology of Race and Ethnicity 5(1):26-40.

Waters, Mary C. 2009. Black Identities: West Indian Immigrant Dreams and American Realities. Cambridge, MA: Harvard University Press.

Watkins-Hayes, Celeste. 2009. The New Welfare Bureaucrats: Entanglements of Race, Class, and Policy Reform. University of Chicago Press.

Weber, Max. [1922] 1968. Economy and Society. Berkeley, CA: University of California Press.

Weber, Max. [1930] 1992. The Protestant Ethic and the Spirit of Capitalism. New York: Routledge.

Weir, Margaret, Ann Shola Orloff, and Theda Skocpol, eds. 1988. The Politics of Social Policy in the United States. Princeton, NJ: Princeton University Press.

Weir, Margaret and Theda Skocpol. 1985. “State Structures and the Possibilities for 'Keynesian' Responses to the Great Depression in Sweden, Britain, and the United States." Pp. 107-64 in Bringing the State Back. In, edited by D. Rueschemeyer, P. B. Evans, and T. Skocpol. Cambridge: Cambridge University Press.

Wilder, Gary. 2005. The French Imperial Nation-State: Negritude and Colonial Humanism Between the Two World Wars. Chicago: University of Chicago Press.

Wilson, Nicholas Hoover. 2011. "From Reflection to Refraction: State Administration in British India, circa 1770-1885.” American Journal of Sociology 116(5):1437-77.

Wimmer, Andreas and Yuval Feinstein. 2010. "The Rise of the Nation-State across the World, 1816 to 2001.” American Sociological Review 75(5):764-90.

Wimmer, Andreas and Brian Min. 2006. "From Empire to Nation-State: Explaining Wars in the Modern World, 1816-2001.” American Sociological Review 71(6):867-97.

Witt, John Fabian. 2009. Patriots and Cosmopolitans: Hidden Histories of American Law. Cambridge, MA: Harvard University Press.

Witt, John Fabian. 2010. "Law and War in American HistoryJohn Fabian WittLaw and War in American History." The American Historical Review 115(3):768-78.

Wyrtzen, Jonathan. 2016. Making Morocco: Colonial Intervention and the Politics of Identity. Ithaca, NY: Cornell University Press.

Zuckerman, Ezra W. 2004. "Structural Incoherence and Stock Market Activity." American Sociological Review 69(3):405-32. 


\section{Tables}

\begin{tabular}{l|l|l} 
Classification & U.S. Code & Definition \\
\hline Alien & $\begin{array}{l}\text { 8 U.S. Code } \$ \\
1101 \text { (a) (3) }\end{array}$ & $\begin{array}{l}\text { The term "alien" means any person not a citizen or national of the United } \\
\text { States. }\end{array}$ \\
\hline Citizen & $\begin{array}{l}\text { 8 U.S. Code } \$ \\
1401\end{array}$ & A person born in the United States, and subject to the jurisdiction thereof. \\
\hline National & $\begin{array}{l}\text { 8 U.S. Code } \$ \\
1101 \text { (a) (22) }\end{array}$ & $\begin{array}{l}\text { The term "national of the United States" means (A) a citizen of the United } \\
\text { States, or (B) a person who, though not a citizen of the United States, owes } \\
\text { permanent allegiance to the United States. }\end{array}$ \\
& &
\end{tabular}

Table 1: Legal Definitions of Citizen, National, and Alien.

(8 U.S. Code ; For more details on the distinction between citizen and national, see Appendix C)

\begin{tabular}{l|l|l} 
Act of U.S. Congress & Issue & Classification \\
\hline 1934 Tydings McDuffie Act & 10 -year trial period toward independence & Aliens \\
\hline 1939 Neutrality Act & Security and peace of the United States & Citizens \\
\hline 1940 Alien Registration Act & Documenting foreigners in the United States & Aliens \\
\hline 1940 Selective Service Act & Military draft & Nationals \\
\hline 1940 Nationality Act & Naturalization of aliens & Aliens \\
\hline 1946 Luce-Cellar Act & Naturalization of Filipinos (and Asian Indians) & Aliens (eligible for citizenship)
\end{tabular}

Table 2: Polysemous Classification of Filipinos, 1934-1946 


\section{Appendix A: Archival Sources}

Asian American Collection, University of California -

Los Angeles, Los Angeles, CA

Anti-Martial Law Movement Special

Collection

Bentley Historical Library, University of Michigan, Ann

Arbor, Michigan

Manuel Luis Quezon Papers

Filipinas Heritage Library, Ayala Museum, Makati, Philippines

Carlos P. Romulo Papers

Franklin D. Roosevelt Presidential Library, Hyde Park, New York

Charles Tauissg Papers

Ernest Cuneo Papers

Franklin D. Roosevelt's Official File

Franklin D. Roosevelt's President's Personal

Files

Franklin D. Roosevelt's President's Secretary

Files

Harold Smith Papers

Harry L. Hopkins Papers

Isador Lubin Papers

Louis M. Howe Papers

Oscar Cox Papers

Samuel Rosenman Papers

Harry S. Truman Presidential Library, Independence, Missouri

Dean G. Acheson Papers

Emmet O’Neal Papers

Frank A. Waring Papers

Harry S. Truman's Official File

Harry S. Truman's President's Personal Files

Harry S. Truman's President's Secretary Files

J. Weldon Jones Papers

RG 51: Records of the Bureau of the Budget

White House Records Offices Files

Hornbake Library, University of Maryland - College

Park, College Park, Maryland

Millard E. Tydings Papers

Lilly Library, University of Indiana, Bloomington, Indiana

Paul V. McNutt Papers

MacArthur Memorial Archives, Norfolk, Virginia

RG 1: Records of the U.S. Military Advisor to the Philippine Commonwealth, 1935-1941

RG 2: Records of Headquarters, U.S. Army

Forces in the Far East (USAFFE), 1941-1942

RG 5: SCAP files

RG 9: Radiogram Messages
RG 10: Personal Correspondence

RG 16: Whitney Papers, 1938-1948, 1950, 1956-65

RG 146: Papers of Lee Telesco

National Archives and Record Administration, College Park, Maryland

RG 59: Department of State

RG 107: Records of the Office of the

Secretary of War

RG 126: Office of the Territories, Classified

Files, 1907-1951

RG 165: Records of the War Department

General and Special Staffs

RG 350: Records of the Bureau of Insular

Affairs

RG 407: Records of the Adjutant General's

Office

RG 496: USAFFE

RG 554: Philippines Command

National Archives and Record Administration, San

Bruno, California

RG 21: Records of District Courts of the United States District of San Francisco

RG 85: Records of the Immigration and

Naturalization Service

National Archives and Record Administration, Washington, DC

RG 15: Records of the Veterans

Administration

RG 85: Records of the Immigration and

Naturalization Service

Center for Legislative Archives

RG 46: Records of the U.S. Senate

RG 233: Records of the United

States House of Representatives

National Library of the Philippines, Manila, Philippines

Sergio Osmeña Papers

Seaver Center, Museum of Natural History, Los

Angeles, California

Philippines Veterans Claims Collection

Sterling Library, Yale University, New Haven,

Connecticut

Henry Lewis Stimson Papers

The Roxas Foundation, Quezon City, Philippines

University of the Philippines Main Library, University

of the Philippines - Diliman, Quezon City,

Philippines

Manuel A. Roxas Papers 


\section{Appendix B: New Deal Era Social Policies and Tools of Exclusion}

\begin{tabular}{|c|c|c|}
\hline & Exclusions/Eligibility written into bill & $\begin{array}{l}\text { Decentralized } \\
\text { Administration }\end{array}$ \\
\hline $\begin{array}{l}\text { Federal Emergency } \\
\text { Relief Administration }\end{array}$ & $\begin{array}{l}\text { - Explicit nondiscrimination (via a memo sent to state relief } \\
\text { administrators) } 1\end{array}$ & Yes \\
\hline $\begin{array}{l}\text { National Labor Relations } \\
\text { Act }\end{array}$ & $-\quad$ Occupational exclusion & No \\
\hline Fair Labor Standards Act & - Occupational exclusion & No \\
\hline $\begin{array}{l}\text { Civilian Conservation } \\
\text { Corps }\end{array}$ & - Excluded women, non-citizens/aliens & Yes \\
\hline $\begin{array}{l}\text { Public Works } \\
\text { Administration }\end{array}$ & $\begin{array}{l}\text { - Set quotas requiring black workers be employed in } \\
\text { proportion to their representation in the occupation census } \\
\text { for each city } \\
\text { - Preferences for citizens and declarants (after ex-servicemen } \\
\text { with dependents) }\end{array}$ & Yes \\
\hline $\begin{array}{l}\text { Civil Works } \\
\text { Administration }\end{array}$ & $\begin{array}{l}\text { - Set quotas requiring black workers be employed in } \\
\text { proportion to their representation in the occupation census } \\
\text { for each city } \\
\text { - } \begin{array}{l}\text { Preferences for citizens and declarants (after ex-servicemen } \\
\text { with dependents) }\end{array}\end{array}$ & Yes \\
\hline $\begin{array}{l}\text { Works Progress } \\
\text { Administration }\end{array}$ & $\begin{array}{l}\text { - } \begin{array}{l}\text { Explicit nondiscrimination (via a memo sent to state relief } \\
\text { administrators) }\end{array} \\
\text { - Over time, Congress added harsher restrictions, first barring } \\
\text { illegal aliens in } 1936 \text { and then all non citizens in } 1939 \text {. In } 1936 \\
\text { the preferences were: first for veterans, then for American } \\
\text { citizens, then for aliens who had taken out papers by the date } \\
\text { the act became law, fourth for aliens who had done so after }\end{array}$ & Yes \\
\hline $\begin{array}{l}\text { (Social Security) Old Age } \\
\text { Insurance }\end{array}$ & $\begin{array}{ll}- & \text { Occupational exclusion } \\
- & \text { Inclusion of aliens } \\
\text { - } & \text { Territory restrictions (in } 1939 \text { amendment) that work must be } \\
& \text { performed in US or on US vessel }\end{array}$ & No \\
\hline $\begin{array}{l}\text { Unemployment } \\
\text { Insurance }\end{array}$ & $\begin{array}{l}\text { - Occupational exclusion } \\
-\quad \text { Inclusion of aliens }\end{array}$ & Mixed \\
\hline Old Age Assistance & 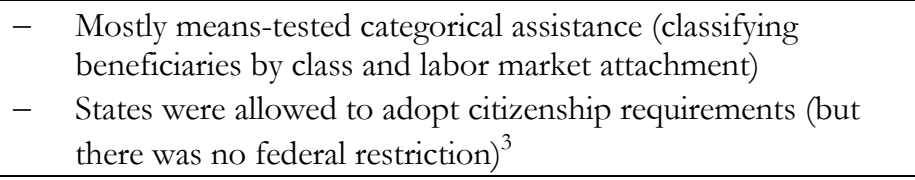 & Yes \\
\hline $\begin{array}{l}\text { Aid to Dependent } \\
\text { Children }\end{array}$ & $\begin{array}{ll}\text { - } & \text { Mostly means-tested categorical assistance (classifying } \\
\text { beneficiaries by class and labor market attachment) }\end{array}$ & Yes \\
\hline GI Bill $^{4}$ & - Some geographic restrictions on use of specific benefits & Yes \\
\hline
\end{tabular}

(Sources: Lieberman (1998), Katznelson (2005), and Fox (2012).)

${ }^{1}$ See Fox (2012: 190)

2 See Fox (2012: 215).

${ }^{3}$ See Fox (2012:266-267)

${ }^{4}$ Note that the G.I. Bill was not a part of FDR's New Deal Program, but I am including here as other scholars, such as Katznelson, have discussed in light of the FDR era expansion of the social welfare system. 


\section{Appendix C: Comparison of Citizen and National Status According to 8} U.S. Code $\int 1401$

\section{Conditions of \\ Citizen/National Status}

Place of Birth within U.S. or

Possessions

\section{Citizen or National}

A person born in the United States, and

subject to the jurisdiction thereof;

A person born in the United States to a member of an Indian, Eskimo,

Aleutian, or other aboriginal tribe:

Provided, That the granting of

citizenship under this subsection shall not in any manner impair or otherwise affect the right of such person to tribal or other property;

\begin{tabular}{|ll}
\hline Place of birth outside U.S. and & A person born outside of the United \\
Possessions & States and its outlying possessions of \\
& parents both of whom are citizens of \\
the United States and one of whom has & had a residence in the United States or \\
& one of its outlying possessions, prior to \\
the birth of such person;
\end{tabular}

A person born outside of the United States and its outlying possessions of parents one of whom is a citizen of the United States who has been physically present in the United States or one of its outlying possessions for a continuous period of one year prior to the birth of such person, and the other of whom is a national, but not a citizen of the United States;

A person born in an outlying possession of the United States of parents one of whom is a citizen of the United States who has been physically present in the United States or one of its outlying possessions for a continuous period of one year at any time prior to the birth of such person;

quisumbing king

\section{Unknown parentage}

A person of unknown parentage found in the United States while under the age of five years, until shown, prior to his attaining the age of twenty-one years, not to have been born in the United States

U.S. parentage
A person born outside the geographical limits of the United States and its outlying possessions of parents one of whom is an alien, and the other a citizen of the United States who, prior to the birth of such person, was physically present in the United States

\section{National}

A person born in an outlying possession of the United States on or after the date of formal acquisition of such possession;

A person born outside the United States and its outlying possessions of parents both of whom are nationals, but not citizens, of the United States, and have had a residence in the United States, or one of its outlying possessions prior to the birth of such person;
A person of unknown parentage found in an outlying possession of the United States while under the age of five years, until shown, prior to his attaining the age of twenty-one years, not to have been born in such outlying possession

A person born outside the United States and its outlying possessions of parents one of whom is an alien, and the other a national, but not a citizen, of the United States who, prior to the birth of such person, was physically present in the United States or its outlying 


\begin{tabular}{|c|c|c|}
\hline & $\begin{array}{l}\text { or its outlying possessions for a period } \\
\text { or periods totaling not less than five } \\
\text { years, at least two of which were after } \\
\text { attaining the age of fourteen years: } \\
\text { Provided, That any periods of } \\
\text { honorable service in the Armed Forces } \\
\text { of the United States, or periods of } \\
\text { employment with the United States } \\
\text { Government or with an international } \\
\text { organization as that term is defined } \\
\text { in section } 288 \text { of title } 22 \text { by such citizen } \\
\text { parent, or any periods during which } \\
\text { such citizen parent is physically present } \\
\text { abroad as the dependent unmarried son } \\
\text { or daughter and a member of the } \\
\text { household of a person (A) honorably } \\
\text { serving with the Armed Forces of the } \\
\text { United States, or (B) employed by the } \\
\text { United States Government or an } \\
\text { international organization as defined } \\
\text { in section } 288 \text { of title } 22 \text {, may be } \\
\text { included in order to satisfy the physical- } \\
\text { presence requirement of this paragraph. } \\
\text { This proviso shall be applicable to } \\
\text { persons born on or after December } 24 \text {, } \\
1952 \text {, to the same extent as if it had } \\
\text { become effective in its present form on } \\
\text { that date; }\end{array}$ & $\begin{array}{l}\text { possessions for a period or periods } \\
\text { totaling not less than seven years in } \\
\text { any continuous period of ten years- } \\
\text { during which the national parent was } \\
\text { not outside the United States or its } \\
\text { outlying possessions for a continuous } \\
\text { period of more than one year, and at } \\
\text { least five years of which were after } \\
\text { attaining the age of fourteen years. } \\
\text { The proviso of section } 1401(\mathrm{~g}) \text { of this } \\
\text { title shall apply to the national parent } \\
\text { under this paragraph in the same } \\
\text { manner as it applies to the citizen } \\
\text { parent under that section. }\end{array}$ \\
\hline $\begin{array}{l}\text { Born before May } 24,1934 \text { to } \\
\text { an alien father and citizen } \\
\text { mother }\end{array}$ & $\begin{array}{l}\text { A person born before noon (Eastern } \\
\text { Standard Time) May 24, 1934, outside } \\
\text { the limits and jurisdiction of the United } \\
\text { States of an alien father and a mother } \\
\text { who is a citizen of the United States } \\
\text { who, prior to the birth of such person, } \\
\text { had resided in the United States. }\end{array}$ & \\
\hline
\end{tabular}

